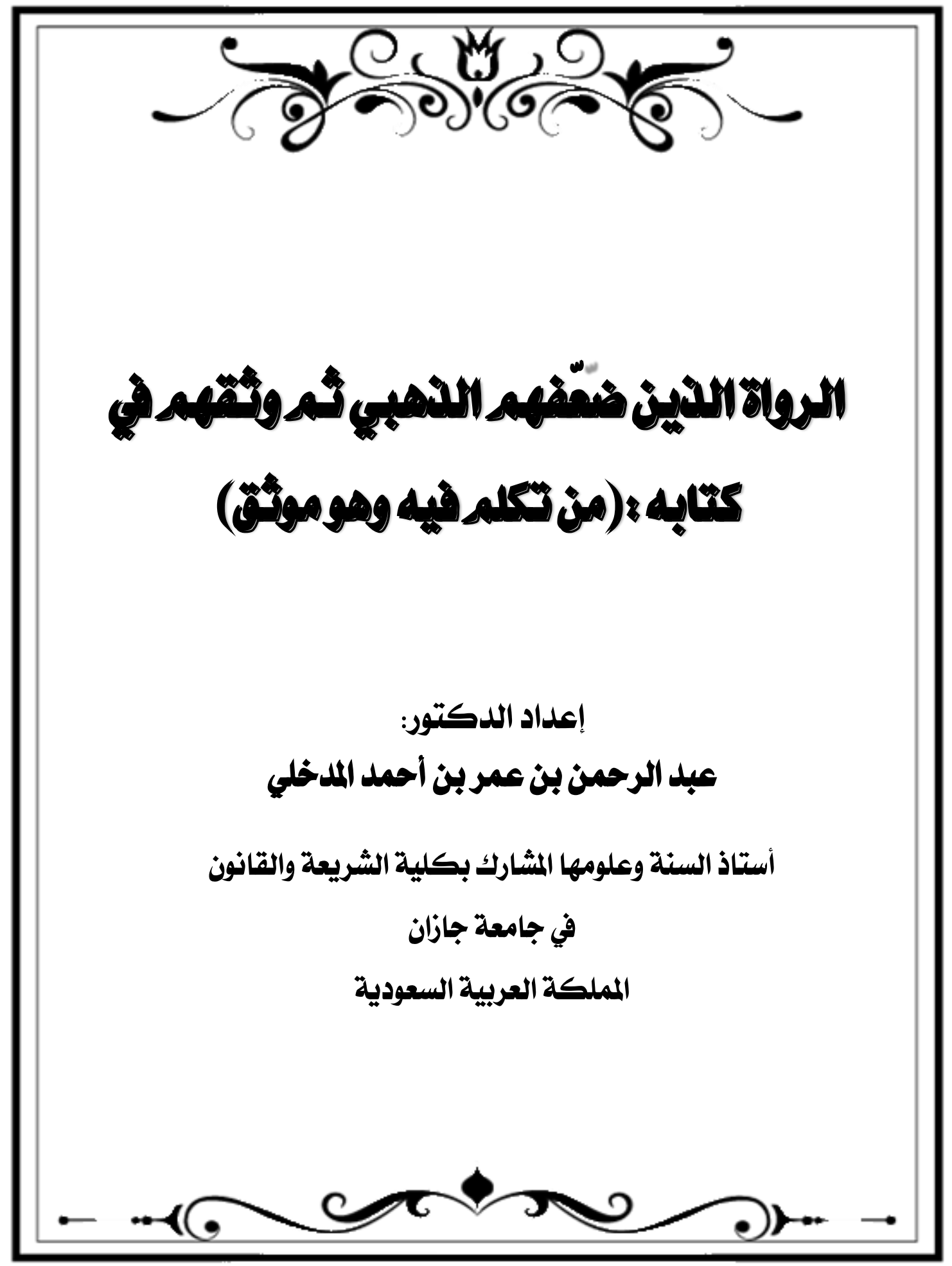




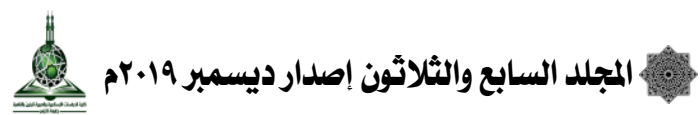

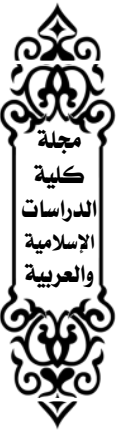




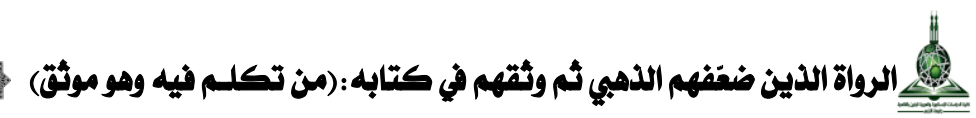
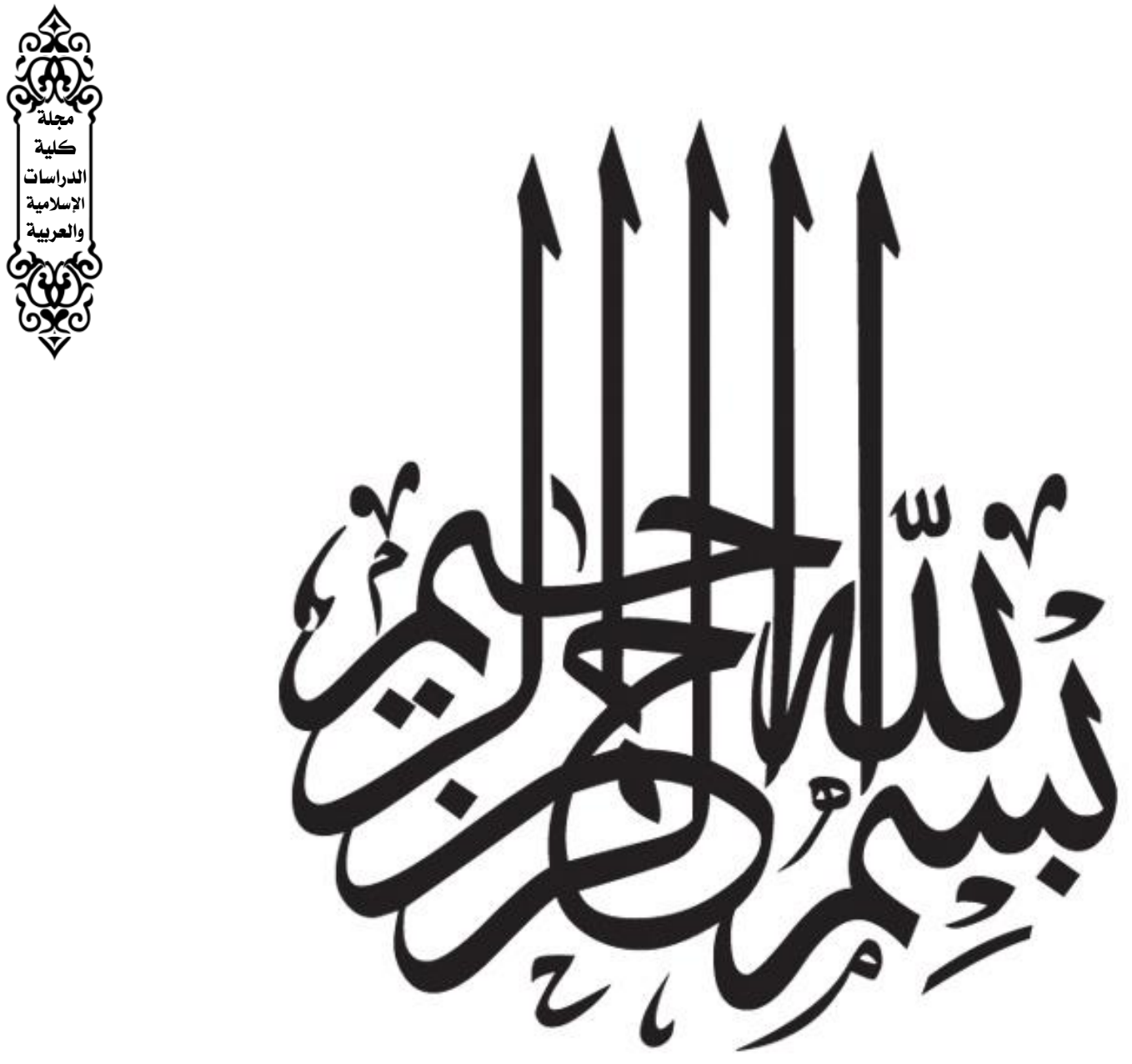


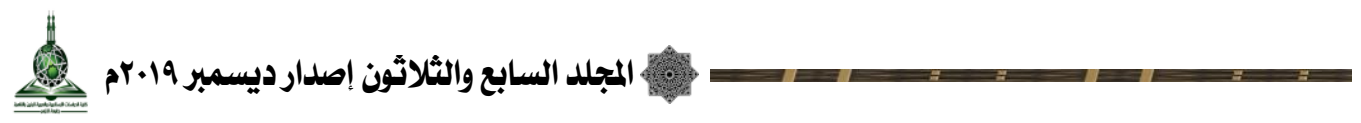


(من تكلـم فيه وهو موثقة)

\section{ماثخم البهُث}

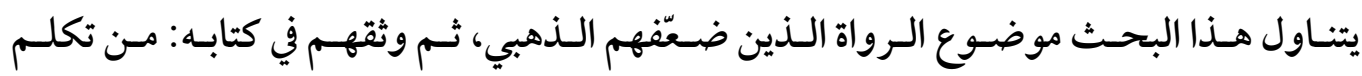

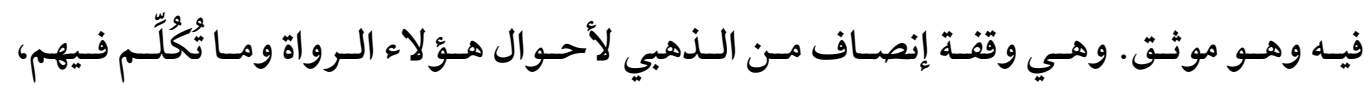

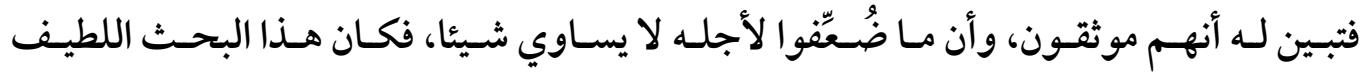

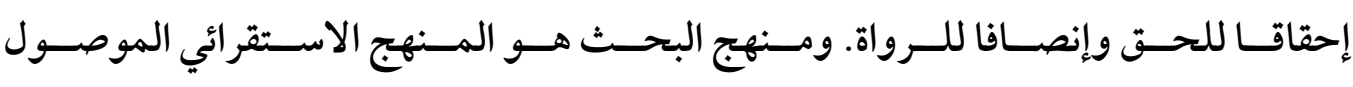
بـالتحليلي. وتــتلخص أهميـة الموضـوع في إرسـال رسـالة إنصـاف في حسق رواة الحسديث.

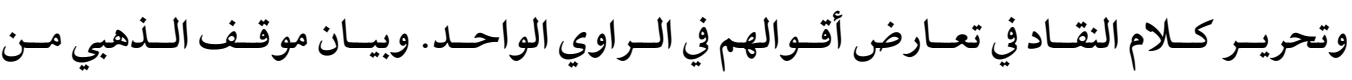

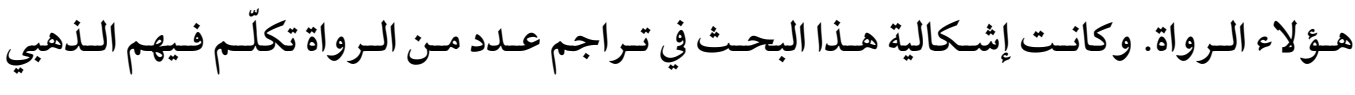

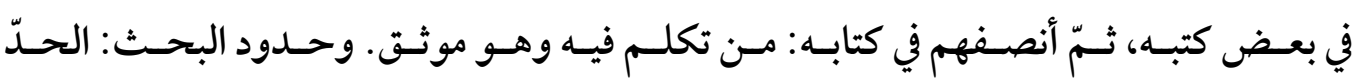
الموضـوعي هـو الـرواة الـذين تكلـم فـيهم الإمـام الـذهبي في كتبـه، ثـم أنصـفهم في كتابـه: مـن تكلـم فيـه وهـو موثـق. وكانـت مـادة البحـث منثورة في كتب الرجـال؛ لكـن لـم أقـف عليها في

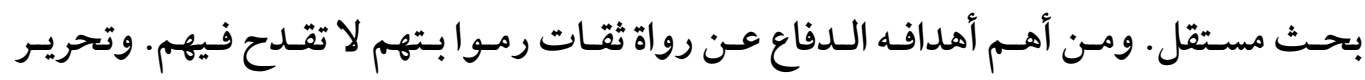

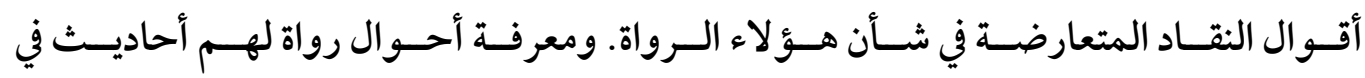

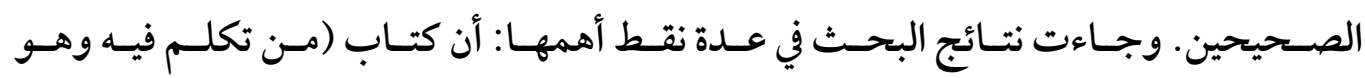

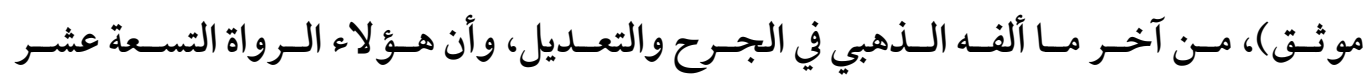
المـذكورون في هـذا البحــث قـد ضـعَفهم الـذهبي في بدايـة تأليفـه، أو مــال إلـى تضـعيفهم في كتبـه، ثـم بــا لـه إنصـافهم فـألّف كتابـه: مسن تكلـم فيسه وهـو موثتق، ولا يوجـد فيهم مسن هـو

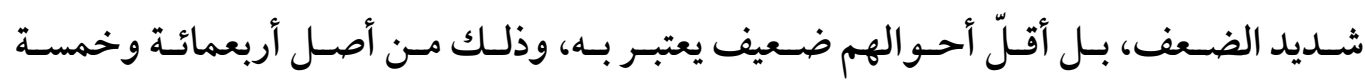
رواة، أودعهم في كتابه المشار إليه. الكلمات المفتاحية: الرواة المختلف فيهم، الثقات المضعفون، الجرح - التعديل. 


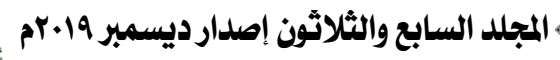

The Narrators discredited by Al-Thahaby although being accredited in his Book: (Those who have been criticised though previously classified as Trustworthy)

By: Abdel-Rahman Bin Omar Bin Ahmed Al-Madkhaly

Associate Professor of Sunnah and its Sciences

Faculty of Islamic Jurisprudence and Law

Jazan University

\section{e.mail: a0505769016@gmail.com}

\section{Abstract}

This research handles the topic of the narrators weakened by Al-Thahaby then he accredited them as trustworthy in his book (Those who have been criticised though previously classified as Trustworthy). It is a fair attitude advocated by AlThahaby towards those narrators and their criticism. He has found out that they are trustworthy and the reason beyond discrediting weakening is nothing at all. Accordingly, this fine research focuses light upon those narrators so as to make them regain their due status. The research follows the inductive analytical approach as its message is to introduce a fair testimony of those narrators. The issue of the research lies in the biographies of some narrators whom Al-Thahaby has handled in his books then fairly accredited them in his book (Those who have been

criticised though previously classified as Trustworthy). The objective framework of the research is limited the narrators mentioned in Al-Thahaby's specified book. The material of the research was distributed in books of scholars but the researcher has not traced it in a single resource. Hence, the research takes as its responssibility to defend the credited trustworthy narrators who have been charged with false accusations. It also displays the controversial statements of the critics handling those narrators as well as tracing life condtions of some narrators who have narrated some prophetic traditions in the two truthful books of Hadith (Assahihan). Finally, the findings of the research are noted in the conclusion. One of those findings is that Al-Thahaby's book (Those who have been criticised though previously classified as Trustworthy) was his last book in the field of (Aljarh wa al-tadeel) dismantling and modifying. In addition, Al-Thahaby intended to discredit the nineteen narrators mentioned in the research at the very beginning of his authorship then he turned his mind and gave them their due status in his well-known book (Those who have been criticised though previously classified as Trustworthy). None of those narrators is utterly discedited. Those narrators are selected from around four-

hundred and fifty ones examined by Al-Thahaby in his mentioned book.

Key words: the disputed narrators, the discredited trustworthy narrators, (Al-jarh wa al-tadeel) dismantling and modifying. 


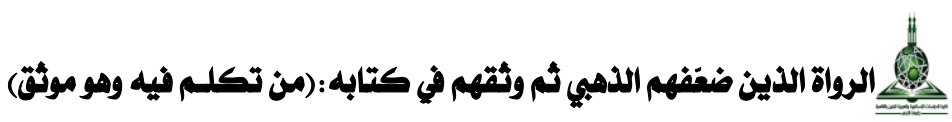
بسم الله الرحمن الرحيم

\section{الاقدمة}

الحمد لله، والصلاة والسلام على رسول الله، وعلى آله وصحبه، أمّابعد:

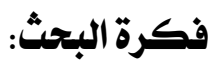

อิด

(S) مجلة كلية |الدراساتية والعربية

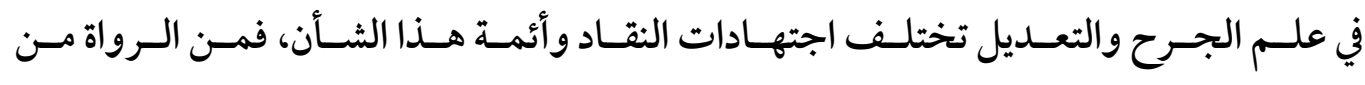
أجمعسو اعلـى توثيقـه، ومسنهم مـن أجمعسو اعلى تضسعيفه، ومسنهم مسن اختلـف اجتهاد النقـاد

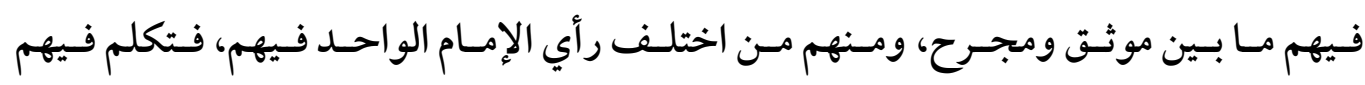

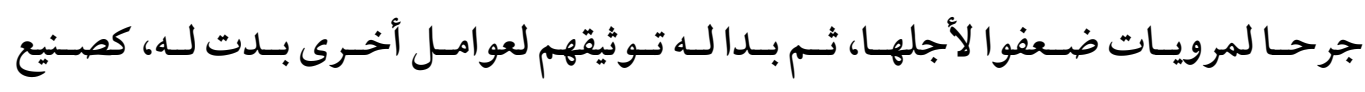
الحـافظ ابـن حبــان؛ فقـــ ذكـر عـددا مـن الـرواة مـرتين، مـرة في كتابـه الثقـات، ومـرة في كتابـهـ

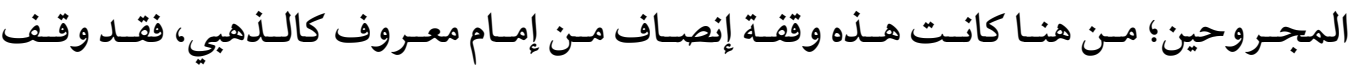

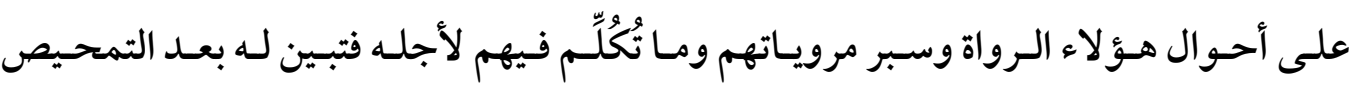

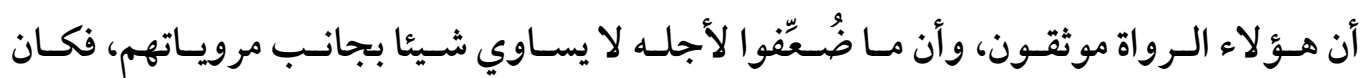
هذا البحث اللطيف، زيادة في التمحيص إحقاقا للحق وإنصافا للرواة. أهمية الموضوع: تكمن أهمية هذا الموضوع في عدة أمور، أهمّها ما يلي:1 - أنه رسالة إنصاف في حق رواة الحديث وحملة العلم . r-أنه تحرير لكلام النقاد في تعارض أقوالهم في الراوي الواحد. r- بأنه بيان موقف الذهبي من هؤلاء الرواة.

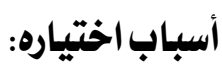
I. رغبة الباحث في الدفاع عن رواة ثقات رُموا بتهم لا تقدح في روايتهم للحديث. r. . . رغبة الباحث في تحرير أقوال النقاد في تعارضها في الر اوي الواحد. r. رغبة الباحث في بيان الراجح في حق كل راوِ وبيان درجته. ع. . رغبة الباحث في الوقوف على أحوال هؤلاء الرواة من خلال مروياتهم. 
هـ رغبة الباحث في إثراء المكتبة الحديثية بهذا البحث اللطيف.

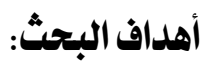
1. ـ الدفاع عن رواة ثقات رموا بتهم لا تقدح في تحملهم للحديث. r. . تحرير أقوال النقاد المتعارضة في شأن هؤلاء الرواة. r. . إثراء المكتبة الحديثية بسرد أحوال هؤلاء الرواة وبيان درجتهم ع. الوقوف على أحوال رواة لهم أحاديث في الصحيحين. ه. التعرف على مناهج الأئمة في إدخالهم للرواة في مصنفاتهم الدراسات السابقة:

مادة هذا الموضوع منثورة في بطون كتب الرجال لكن لم أقف على من أفردها ببحث مستقل منهج البحث: مادة هدر الدو

1 - استخراج من غلب عليه صفة التوثيق في كتاب الذهبي: من تكلم فيه وهو موثق، وعددهم تسعة

$$
\text { عشر راويا، من أصل أربعمائة وخمسة رواة. }
$$

r-بيان الكتب التي خرّجت أحاديثهم، باستعمال الرموز التي اصطلح عليها أهل هذا الفنّ. r-الترجمة المختصرة لكل راوٍ، وذكر أشهر شيوخه وتلاميذه من الذين ذكرهم المزي في تهذيب

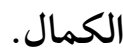

ع -استقر اء كلام الذهبي في هؤلاء الرواة في كتبه المختصة بالجرح والتعديل، ثم الوقوف على آخر كلامه في الر اوي من خلال كتابه: من تكلم فيه وهو موثق. ه-استخر اج كلام النقاد في هؤلاء الرواة من خلال كتب الجرح والتعديل. צ-المقارنة بين كلام النقّاد وكلام الذهبي، ثم الترجيح بما يبين حال الراوي وفق قواعد الجرح والتعديل عند تعارض الأقوال، مع الاستئناس بكلام المتأخرين في تحرير درجة الراوي، وأحكامهم العملية في الحكم على مروياته.

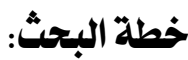
اقتضث طبيعة البحث أن يكون من مقدمة وخاتمة وبينهما الرواة مرتبة أسماؤهم على حروف 
أما المقدمة: فتحتوي على فكرة البحث، وأهمية الموضوع، وأسباب اختياره، وأهداف البحث، والدراسات السابقة، ومنهج البحث، والخطة، وتوطئة، ثم الرواة مرتبة أسماؤهم على حروف 


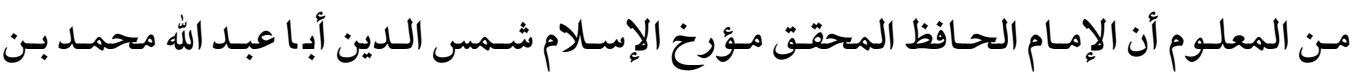

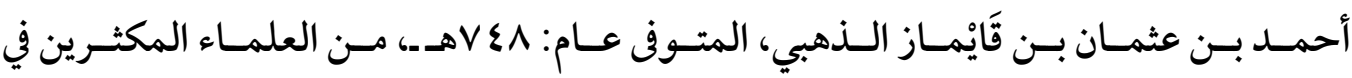
التـأليف في جميـع فـروع العلـم، ومنهـا: التصـنيف في التـراجم والجـرح والتعـديل، و أضسحت

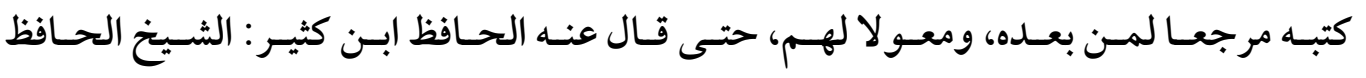

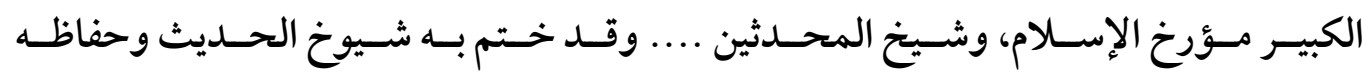

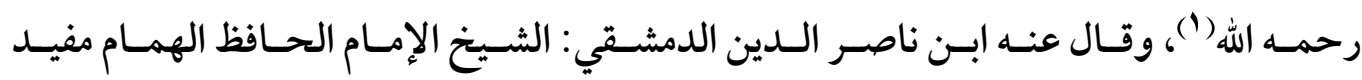

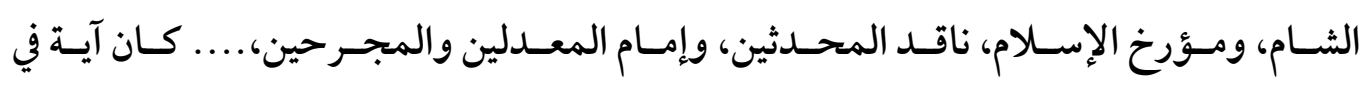

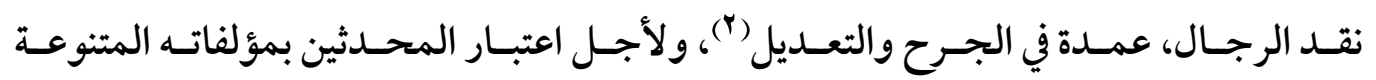
وتحقيقاته الفريدة كانت هذه الدراسة. وقبل الشروع في ذكر الرواة الذين تكلّم فيهم، ثمّ وثقهم في كتابه: من تكلم فيه وهو موثق؛ كان لزاما علينا معرفة تواريخ تأليف تيك الكتب التي سنستقي منها أقوال الإمام الذهبي، لما ينبني على ذاكم من معرفة أحكامه المتقدمة أو المتأخرة؛ ولكن سيكتنف ذلك ملحظان: أحدهما: ليس كلّ الكتب معلومٌ تاريخ تأليفه، فبعضها غُلفُ من ذلك؛ ولكن قد يستدلّ بقر ائن تقرّب لنا ما نروم، كما سيأتي. ثانيهما: أنّ الإمام الذهبيّ ـ كغيره من المصنفين ـ قد يؤلف كتابا في وقت من الأوقات ثم لايزال يتعاهده بالحذف والإضافة إلى أمد بعيد. وسأذكر الآن الكتب التي عليها مدار بحثنا هذا، وتواريخ تأليفها: الكاشف في معرفة من له رواية في الكتب الستة: موضوع هذا الكتاب فكرته ذكرها الذهبي في مقدمثه، فقال: هذا مختصر نافع في رجال الكتب الستة: الصحيحين، والسنن الأربعة، مقتضب من

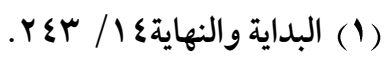

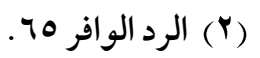




\section{الرواة الدين ضعفهم الدهبي ثم وثقهم في كتابه :(من تكلسم فيه وهو موثقة)}

تهذيب الكمال- لشيخنا الحافظ أبي الحجاج المزي، اقتصرت فيه على ذكر من له رواية في

الكتب، دون باقي تلك التواليف التي في التهذيب- ودون من ذكر للتمييز، أو كرر للتنبيه (1). وقد انتهى الذهبي من تأليفه في / / / P / Pـ، كما جاء في آخر نسخة الظاهرية، حيث قال: تمّ الكاشف ـ والحمد لله - يوم سابع عشر، من رمضان، سنة عشرين وسبعمائة، يوم الجمعة بعد

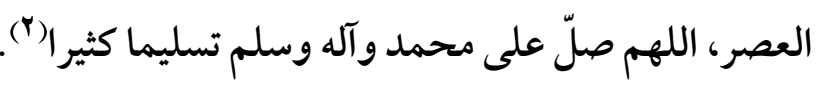
الديوان في الضعفاء والمتروكين وخلق من المجهولين وثقات فيهم لين: قال محققه الشيخ حماد الأنصاري: والكتاب من أهم ما كتبه الحافظ الذهبي في بابه(َ).

ولم يذكر المؤلف تاريخ تأليفه؛ لكن ذكر تلميذه ابن تغري بردي أنّه ألّفه قبل المغني في

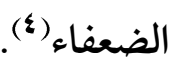

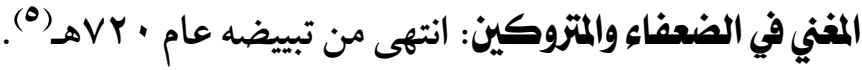
ميزان الاعتدال في نقد الرجال: انتهى من تأليفه عام ع Vهـ، واستمرّ في مر اجعته والزيادة عليه، وتصحيح بعض الأخطاء، في مدة تصل إلى أربع سنين(")، وقال في مقدمته: فهذا كتاب جليل مبسوط .... ألفته بعد كتابي المنعوت بالمغني (V)، وقال في الموقضة: فأمّا من ضعّف أو قيل فيه أدنى شيء فهذا قد ألفت فيه مختصرا سميته بـالمغني، وبسطت فيه مؤلفا سميته بـالميزان(^).

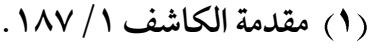

(Y) انظر : مقدمة الشيخ محمد عوامة لتحقيق كتاب الكاشف 1/ 101 .

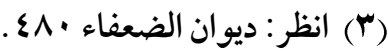
(ع) انظر : ضوابط الجرح والتعديل عند الحافظ الذهبي ه1.

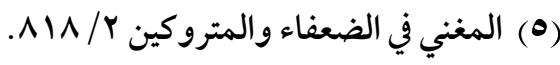

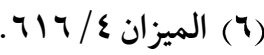

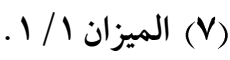

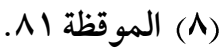


وقد أحال في الميزان إلى كتابه المغني (')، مما يرجح تقدم تأليف المغني. تذكرة الحفّاظ: لم يذكر تاريخ تأليفه؛ لكنه قبل تأليفه لسير أعلام النبلاء، حيث أحال في السير إلى التذكرة(汭 ومما يؤكد ذلك أنّه قال في السير، في ترجمة محمد بن رمح: لم يتفق لي أن أورد ابن

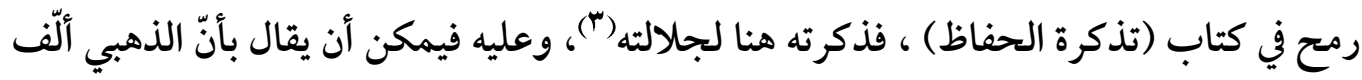

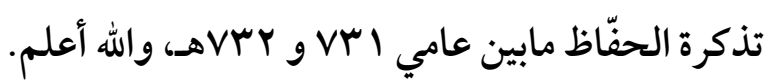
سير أعلام النبلاي: لم يذكر تاريخ تأليفه؛ لكن يفهم من بعض إشاراته في التراجم آنّه بدأ تأليفه حو الي عام Y YVهـ، وانتهى منه حوالي عام ه هVهـ، مع ما لحق ذلك من النظر فيه وتبيضه إلى عام

(8) ovra

من تكلم فيه وهو موثق: هذا الكتاب حدد مؤلفه غرضه من تأليفه، فقال في مقدمثه: فهذا فصل نافع، في معرفة ثقات الرواة الذين تكلم فيهم بعض الأئمة بما لا يوجب رد أخبارهم، أو فيهم بعض اللين، وغيرهم أتقن منهم وأحفظ، فهؤلاء حديثهم إن لم يكن في أعلى مراتب الصحيح فلا ينزل عن رتبة الحسن، اللهم إلا أن يكون للرجل منهم أحاديث تستنكر عليه، وهي التي تكلم فيه من أجلها، فينبغي التوقف في تلك الأحاديث، والله الموفق للحق بمنه (ه). ولـم يـذكر المؤلـف تـاريخ تأليفـهـ لهـذا الكتـاب؛ والأرجـح أنّهـ ألّفـه بعـد كتـاب الميـزان،

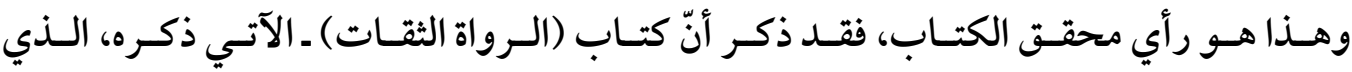
صـرّح فيسه الـذهبي بأنّهـ ألّفـهـ بعـد الميـزان، كمـا سـيأتي ـ متـأخر عـن كتـاب: (مسن تكلـم فيسه وهـو موثـق)، حيـث قـال: كـأن الإمـام الـذهبي نظـر في هـذه الرسـالة ـ يعني مـن تكلـم فيـه وهـو

(1) الميزان / / I I ا.

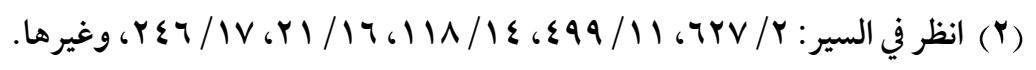

$$
\begin{aligned}
& \text { (") سير أعلام النبلاء 11 / } 199 \text { ـ. }
\end{aligned}
$$

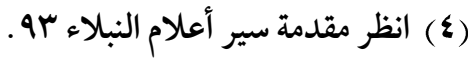

$$
\begin{aligned}
& \text { (0) من تكلم فيه وهو موثق } 07 .
\end{aligned}
$$




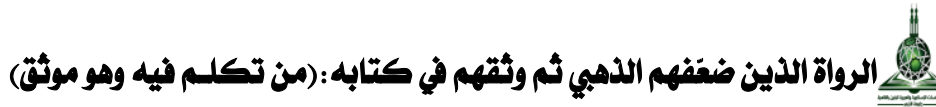

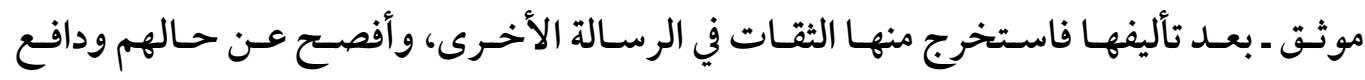

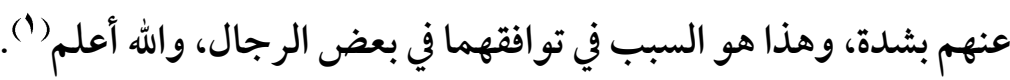
الرواة الثقات التكلم فيهم بما لا يوجب ردهم:

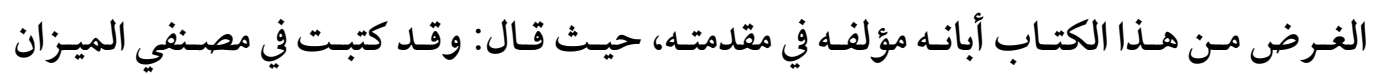

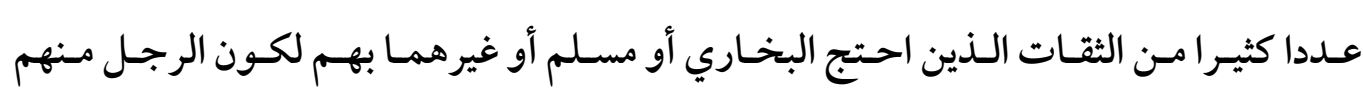

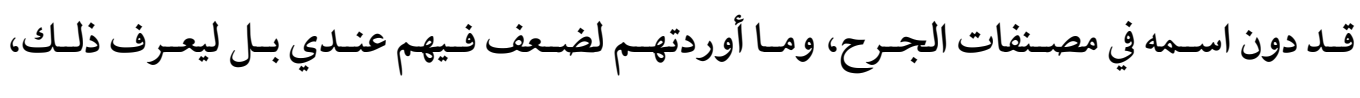

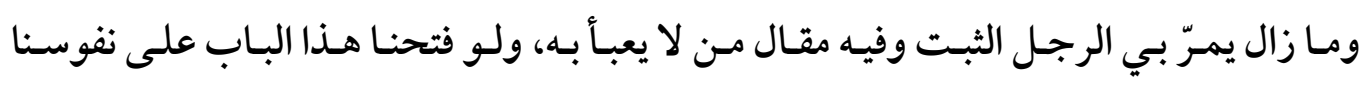

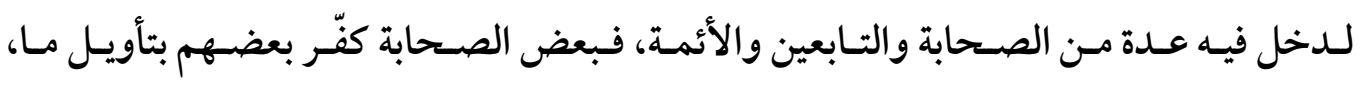

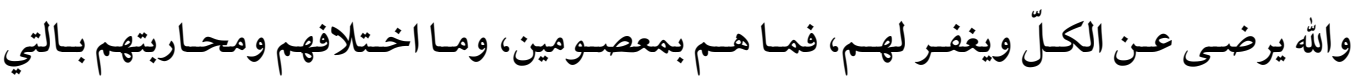
تليّنهم عندنا أصلال) ولـم يـذكر المؤلـف تـاريخ تأليفهـ لهـذا الكتـاب؛ لكنّـك تـرى مـاذكره في مقدمته مـن أنّهـ

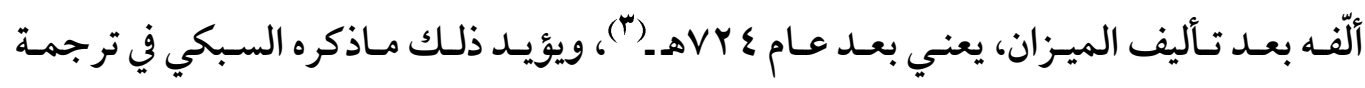

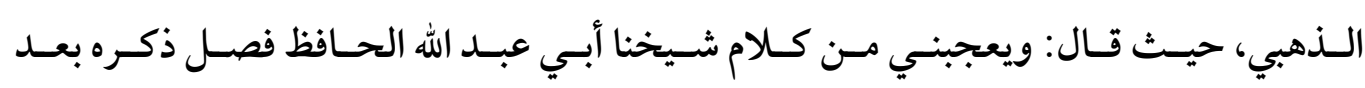

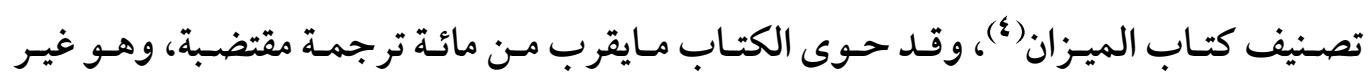

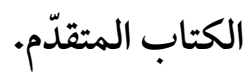
خلاصة: مما سبق يتبيّن أنّ هذين الكتابين الأخيرين هما آخر ماصنّف الإمام الذهبي في الجرح

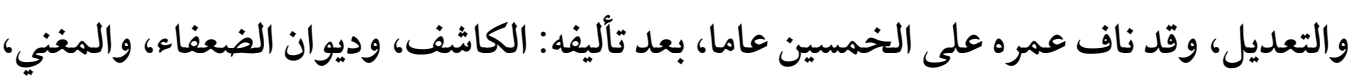

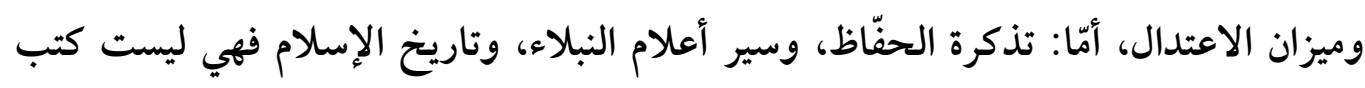

(1) انظر مقدمة تحقيق من تكلم فيه وهو موثق سا . (ץ) الرواة الثقات بr.

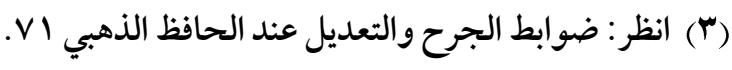

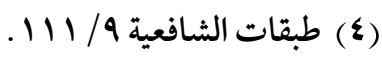


مختصّة في الجرح والتعديل، وإنّما هي كتب تاريخ وتر اجم عامّة، وقد يذكر فيها الجرح والتعديل عَرَضا، وذكرتهما للاستئناس بهما.

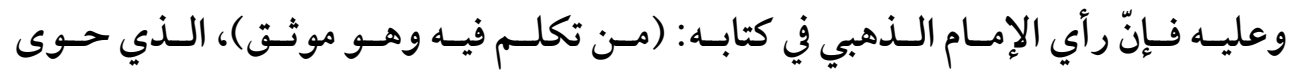

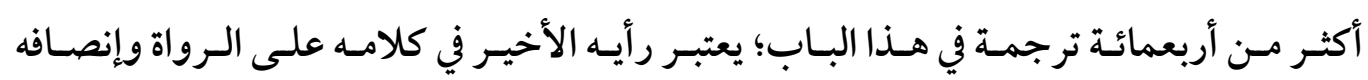

لهم، بعد طول خبرة في هذا العلم، والله تعالى أعلم.

وسـوف أعتبـر هـذه النتيجـة خـلال تــراجم الـرواة في هـذا البحـث، وأعتمـد كلامـه في هـذا

الكتاب على آنّه آخر أقواله في الراوي.

وهذا أوان الشروع في المقصود، وعلى الله الاعتماد، ومنه أستمدّ العون سبحانه: 


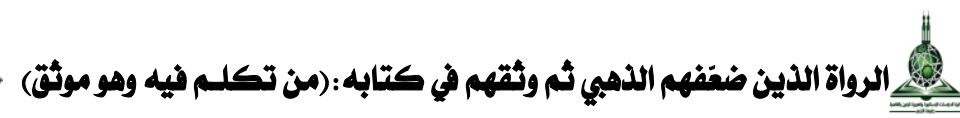

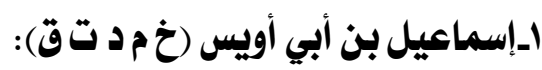

هو: إسماعيل بن عبد الله الأصبحي، أبو عبد الله المدني، وهو ابن أخت مالك بن أنس ونسيبه (1). رَوَى عن: خاله مالك بن أنس، وأخيه أبي بكر، وأبيه عبد الله(َ)، وغيرهم. روَى عنه : البخاري ومسلم وأحمد بن صالح المصري (")، وغيرهم.

وثقه أحمد (\&)، وابن أبي حاتم، وقال: كان ثبتا في حديث خاله مالك، ومرة قال: كان من الثقات(•)، وذكره ابن حبان في الثقات(").

قال ابن عدي: روى عن خاله مالك أحاديث غر ائب لا يتابعه عليها أحد(V)، وقال يحيى بن معين: صدوق ضعيف العقل ليس بذاك، ومرة قال: إسماعيل بن أبي أويس لا يساوى فلسين(^)، وقال النسائي: ضعيف، وقال في موضع آخر : غير ثقة(9)، وقال اللالكائي: بالغ النسائي في الكلام عليه إلى أن يؤدي إلى تركه، ولعله بان له ما لم يبن لغيره، لأن كلام هؤلاء كلهم يؤول إلى أنه ضعيف(·) ، وقال الدارقطني: لا أختاره في الصحيح، وقال مرة: ضعيف('")، وجاء في سؤالات

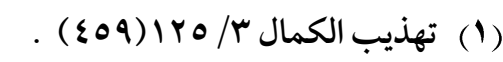

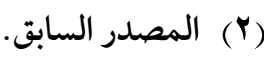

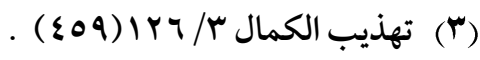

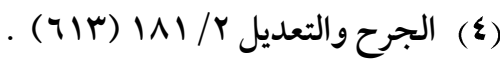

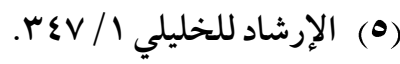

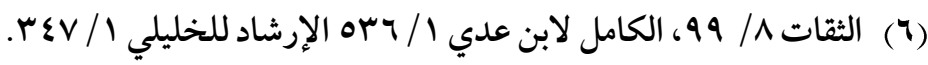

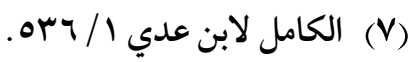
. AV// الضعفاء الكبير للعقيلي (A)

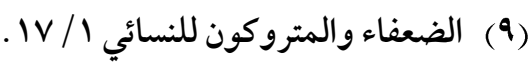

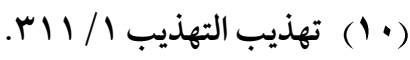

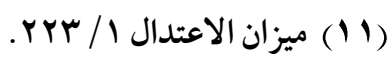


البرقاني للدارقطني: قلت لأبى الحسن: لم ضعف أبو عبد الرحمن النسائي إسماعيل بن أبى أويس؟ فقال: ذكر محمد بن موسى الهاشمي، قال أبو الحسن: وهذا أحد الأئمة، وكان أبو عبد الرحمن يخصه بما لم يخص به ولده، فذكر عن أبى عبد الرحمن أنه قال: حكى لي سلمة بن شبيب عنه، قال: ثم توقف أبو عبد الرحمن، قال: فما زلت بعد ذلك أداريه أن يحكى لي الحكاية، حتى قال لي: قال لي سلمة بن شبيب: سمعت إسماعيل بن أبى أويس يقول: ربما كنت أضع الحديث لأهل المدينة إذا اختلفوا في شيء فيما بينهم(') وعلق ابن حجر على هذه الحكاية بقوله: قلت: وهذا هو الذي بان للنسائي منه حتى تجنب حديثه وأطلق القول فيه بأنه ليس بثقة، ولعل هذا كان من إسماعيل في شبيته ثم انصلح، وأما الشيخان فلا يظن بهما أنهما أخرجا عنه إلا الصحيح من حديثه الذي شارك فيه الثقات، وقد أوضحت ذلك في مقدمة شرحي على البخاري(؟). موقف الذهبي منه:

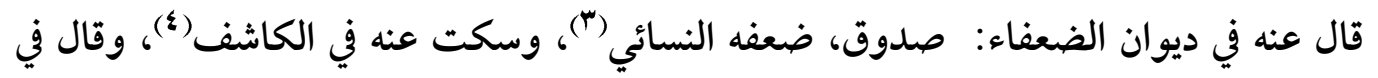
المغني: صدوق له مناكير، ضعفه لذلك النسائي (ه)، وقال في الميزان: محدّث مكثر، فيه لين (6)، وآخر أقواله فيه: صدوق مشهور ذو غرائب(v). والذي يترجح: أنه صدوق يخطئ من حفظه، وهذا ما قرره الذهبي هنا، وفي السير؛ حيث قال: كان عالم أهل المدينة ومحدثهم في زمانه على نقص في حفظه وإتقانه، ولولا أن الشيخين احتجا به

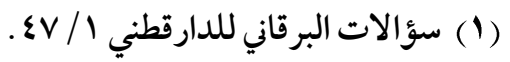

$$
\begin{aligned}
& \text { (ץ) تهذيب التهذيب / / / }
\end{aligned}
$$

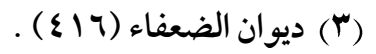

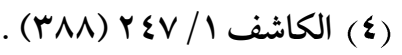

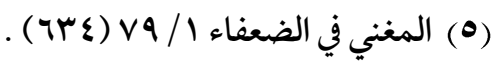

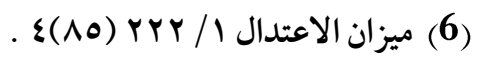

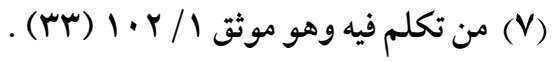




\section{الرواة الدين ضعفهم الدهبي ثم وثقهم في كتابه: (من تكلم فيه وهو موثق)}

لزحزح حديثه عن درجة الصحيح إلى درجة الحسن، هذا الذي عندي فيه(')، وهو ما قرره ابن حجر في التقريب، فقال: صدوق أخطأ في أحاديث من حفظه(r)، وقد رمز له في آخر اللسان بـ(هـ): وهم المختلف فيهم والعمل على توثيقهم (")، وقد احتجّ به الشيخان إلا أنهما لم يكثر ا من تخريج حديثه، ولا أخرج له البخاري مما تفرد به سوى حديثين، وأما مسلم فأخرج له أقل مما أخرج له

البخاري، وروى له الباقون سوى النسائي(؛)، وأما استثناء أحاديث الشيخين؛ فلما سبق أن قرره الحافظ في التهذيب من قوله: وأما الشيخان فلا يظن بهما أنهما أخر جا عنه إلا الصحيح من حديثه الذي شارك فيه الثقات.ا.هـ، وأمّا البخاري فقد كان إسماعيل من شيوخه الذين جالسهم وعرفهم وسبر حديثهم، وقد روى عنه انتقاء من حديثه واعتمادا على أصوله التي أخرجها للبخاري؛ قال

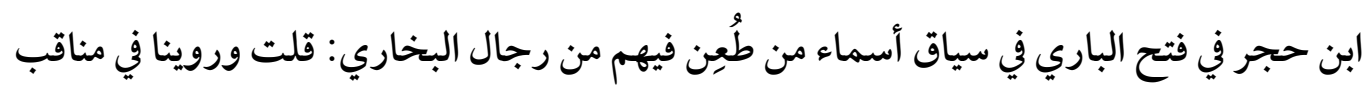
البخاري بسند صحيح أن إسماعيل أخرج له أصوله وأذن له أن ينتقي منها، وأن يعلم له على ما يحدث به ليحدث به، ويعرض عما سواه، وهو مشعر بأن ما أخرجه البخاري عنه هو من صحيح حديثه لأنه كتب من أصوله، وعلى هذا لا يحتج بشيء من حديثه غير ما في الصحيح من أجل ما قدح فيه النسائي وغيره إلا إن شار كه فيه غيره فيعتبر فيه(ه)، والله أعلم.

(1) السير // إ؟ (170).

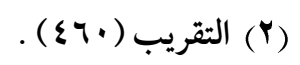

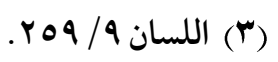
(ع) هدي الساري الهب. (•) فتح الباري / ع^r. 


\section{بـحرِيرِّ( (1) بن عثمان الرحبى الحمصي (خ ع):

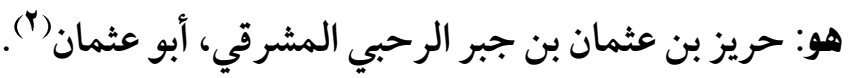
روى عن: عبد الله بنْ بُسر المازني الصحابي، وخالد بن معدان، وراشد بن سعد، وغيرهم. روى عنه: بقية، والوليد بن مسلم، ويزيد بن هارون، ويحيى الوحاظي، وغيرهم. أقوال الأئمة فيه: قال عنه أحمد بن حنبل: صحيح الحديث(")، وقال الآجري عن أبي داود: شيوخ حريز كلهم ثقات، قال: وسألت أحمد بن حنبل عنه فقال: ثقة ثقة، وقال أيضًا: ليس بالشام أثبت من حريز (๕)، وقال البخاري: قال أبو اليمان: كان حريز يتناول من رجل - يعني عليا - ثم ترك(•)، وقال أبو حاتم الرازي: حسن الحديث، ولم يصحّ عندي ما يقال في رأيه، ولا أعلم بالثام أثبت منه، هو أثبت من

صفوان بن عمرو، وأبي بكر ابن أبي مريم، وهو ثقة متقن ("). وذكره ابن معين في تاريخه، ونقل نفي علي بن عياش أنه كان يسب عليا رضي الله عنه(V).

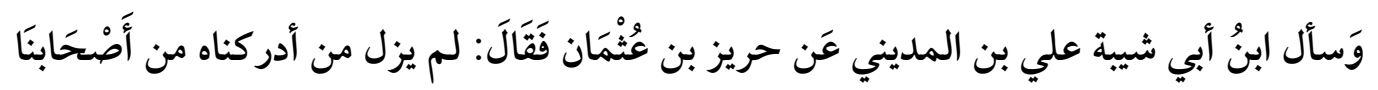
يوثقونه(^)، وقال ابن عدي: كان من ثقات الشاميين، وإنما وضع منه بغضه لعلي (9)، وقال العجلي:

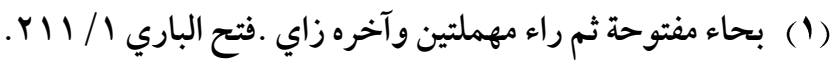
(Y) تهذيب الكمال / / 1 / IV0ه ).

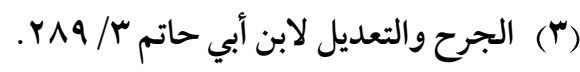

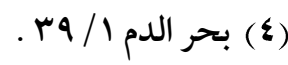

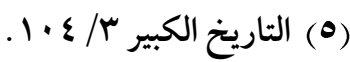

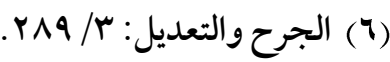

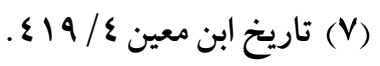

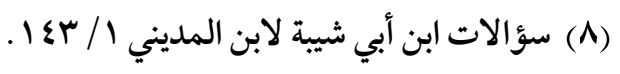
(q) الكامل 


\section{الرواة الدين ضعفهم الدهبي ثم وثقهم في كتابه: (من تكلم فيه وهوموثق)}

ثقة، وكان يحمل على علي (1)، وقال ابن حبان: كان يلعن عليا، وكان داعية إلى مذهبه("). موقف الذهبي منه: قال عنه في ديوان الضعفاء: شامي ثقة؛ لكنه ناصبي مبغض، وأما علي بن عياش فسمعه يقول: والله ما شتمت عليا قط (")، وقال في الكاشف: ثقة، له نحو مائتي حديث، وهو ناصبي (\&)، وقال في المغني: تَابِيعِي صَغِير ثَبَّ؛ لكنه ناصبي (ه)، وقال عنه في السير : الحافظ العالم المتقن(")، وقال عنه في الميزان: كان متقنا ثبتا؛ لكنه مبتدع، ورمز له بالرمز (صح) والمعنى أن العمل على توثيقه(V)، وقال في رسالة الثقات: قلّ من يوجد في الشاميين في إتقانه، وثّقة غير واحد؛ لكنه ناصبي ـ نسأل الله السلامة ـ إلا أنه لا يسب(^)، وآخر أقواله فيه: ثقة، متقن، تكلم فيه لنصبه(9). والذي يترجح: أنه ثقة، فقد أطبق كبار النقّاد على توثيقه، له عند البخاري حديثان فقط، وروى له أصحاب السنن(·)، وأما ما نسب إليه من النصب فهي تهمة رُمي بها، ونفاها عن نفسه وأقسم على ذلك ـ كما نقل ابن عياش ـ أو لعل ذلك كان في أول أمره ثم ترك، وهذا أعدل الأقوال؛ قال أبو الوليد الباجي بعدما ذكر اختلاف النقاد في حريز: لا يُخْتَلف فِيهِ، ثَبَت فِي الحَدِيث (1').

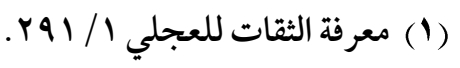

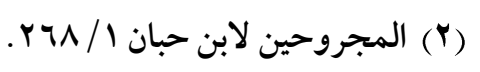

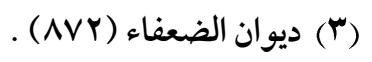

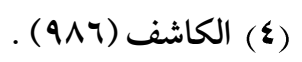

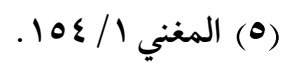

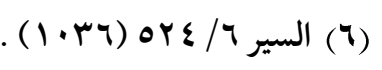

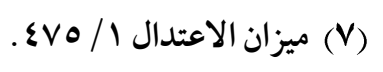

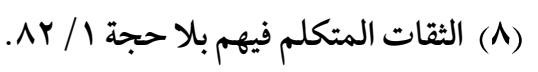

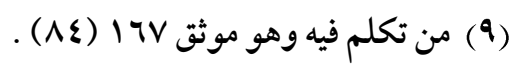

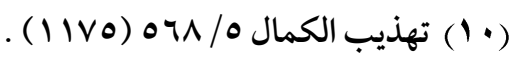

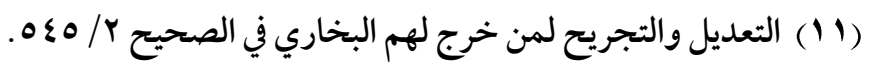


وقـال ابـن حجـر : وثقــه أحمــد وابـن معـين والأئمـة؛ لكـن قـال الفـلاس وغيـره أنـه كـان ينتقصص

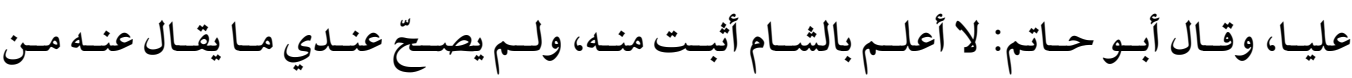
النصـب، قلـت: جـاء عنـه ذلك مـن غيـر وجـه، وجـاء عنـه خـلاف ذلك، وقـال البخـاري: قـال

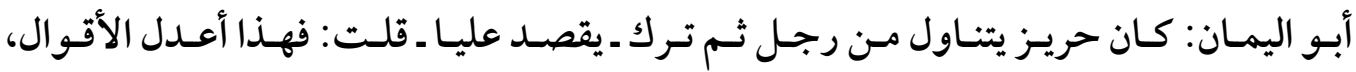

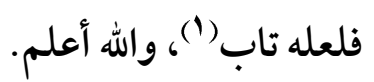
rـ عاصم بن كليب الجرمي (خت م ع): هو: عاصم بن كليب بن شهاب ابن المجنون الجرمي الكوفي. روى عن: أبيه، وأبي بردة، وعلقمة بن وائل، ومحمد بن كعب القرظي، وغيرهم(َ). روى عنه : ابن عون، وشعبة، والسفيانان، وغيرهم (").

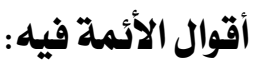

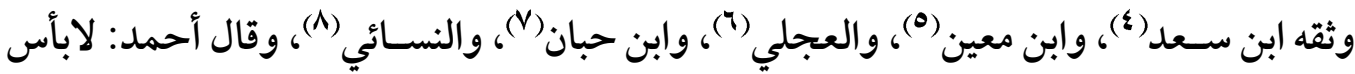
به (9)، وقال أبو عبيد الآجري: قلت لأبي داود: عاصــم بن كليب، ابن من؟ قال: ابن شـهاب الجرمي، كان من العُبّاد، وذكر من فضله، قلت: كان مرجئا؟ قال: لا أدري، وقال في موضع آخر:

$$
\begin{aligned}
& \text { (1) فتح الباري / דهץ. }
\end{aligned}
$$

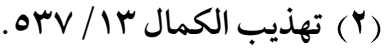

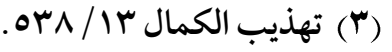

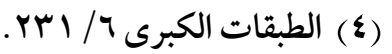

$$
\begin{aligned}
& \text { (0) تهذيب الكمال r / / }
\end{aligned}
$$

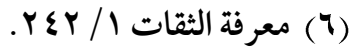

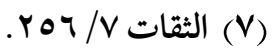

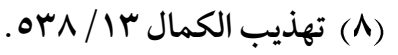

$$
\begin{aligned}
& \text { (9) الجرح والتعديل ؟ / • هـ. }
\end{aligned}
$$




\section{الرواة الدين ضعفهم الدهيي ثم وثقهم في كتابه : (من تكلم فيه وهو موثق)}

كان أفضـل أهل الكوفة(1)، وقال أبو حاتم الرازي: صـالح(؟)، وذكره العقيلي في الضـعفاء، ونقل عن شريك بن عبد الله النخعي أنه كان مرجئا(")، وقال علي بن المديني: لا يحتج به إذا انفرد(\&). موقف الذهبي منه: قال عنه في ديوان الضعفاء: صدوق (•)، وقال في المغني: كان من الأولياء، ثقة(")، وقال عنه في تاريخ الإسلام: كان فاضلا عابدا(V)، وقال عنه في الميزان: وكان من العباد الأولياء؛ لكنه مرجئ(A)، وآخر

أقو اله فيه: ثقة وليٌّ لله تعالى (9). والذي يترجح: أنه ثقة؛ وَثَّقَهُ جمع من الأئمة، ورووا عنه، قال يعقوب بن سفيان: روى عنه شعبة وزائدة والأئمة، كوفي ثقة(· (1. هـ، وهو من رجال مسلم، وأما جرح علي بن المديني فلم ينقله إلا ابن الجوزي، ولا يوجد في كتب المتقدمين، وهو وإن صحّ فلا يقاوم توثيق الأئمة له، وأما ما رمي به من الإرجاء فلم ينقل إلا عن شريك بن عبد الله النخعي.

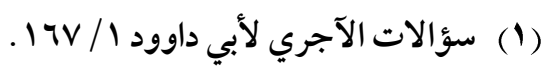

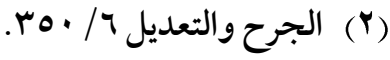

$$
\begin{aligned}
& \text { (r) الضعفاء الكبير / ؟ ؟r. }
\end{aligned}
$$

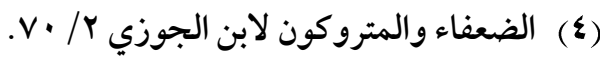

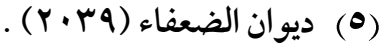

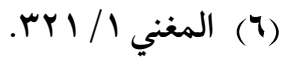

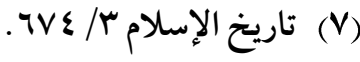

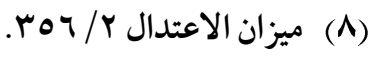

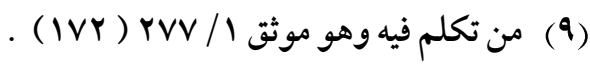

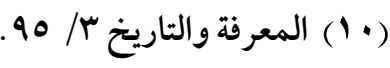


عـ عاصم بن أبي النجود (ع):

هو: عاصم بن بَهْدَلة ـوهو ابن أبي النَّجُود ـ الأسدي مودو لاهم، الكوفي، أبو بكر المقرئ(1). روى عن: أبي عبد الرحمن السلمي، وزرّ بن حبيث وحدث عنهما، وعن أبي وائل، وغيرهم(َ). روى عنه: شعبة، والحمادان، والسفيانان، وزائدة، وشيبان، وأبو عوانة، وغيرهم (َّ). أقوال الأنمة فيه: قال أحمد بن حنبل: كان رجلاً صالحًا قارنًا للقر آن، وأهل الكوفة يختارون قراءته، وأنا أختارها، و كان خيّرًا ثقة (๕)، وقال ابن معين: لا بأس به(•)، وقال العجلي: عاصم صاحب سنة وقر اءة للقر آن، و كان ثقة، رأَسًا في القراءة(")، وقال أبو زرعة: ثقة(V)، وقال النسائي: ليس به بأس، وقال مرة: ليس بحافظ(^)، وقال البزار: لا نعلم أحدا ترك حديثه مع أنه لم يكن بالحافظ(9)، وقال ابن خراش: في حديثه نكارة(·")، وقال العقيلي: لم يكن فيه إلا سوء الحفظ('")، وقال الدارقطني: في حفظه شيء(r)"، وقال أبو حاتم: صدوق، ومرة قال: ليس محله أن يقال ثقة(r ().

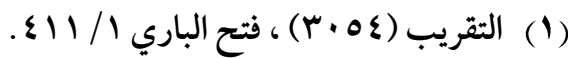

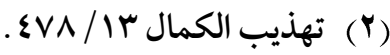

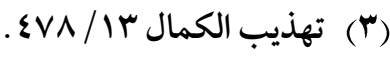

$$
\begin{aligned}
& \text { (ع) المصدر السابق. }
\end{aligned}
$$

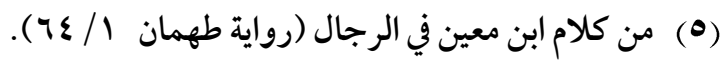

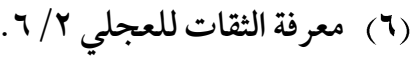

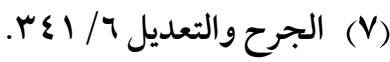

$$
\text { (A) }
$$

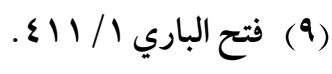

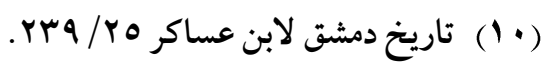

(11) (1) المصدر السابق.

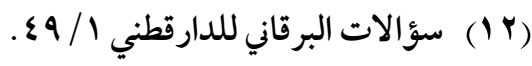

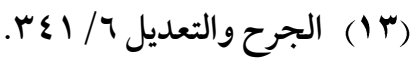




\section{الرواة الدين ضعفهم الدهبي ثم وثقهم في كتابه : (من تكلم فيه وهو موثقة)}

موقف الذهبي منه:

قال عنه في ديوان الضعفاء: إمام صدوق(')، وقال عنه في الكاشف: وُوثِّق ()، وقال عنه في الميزان: ثبت في القراءة، وهو في الحديث دون الثبت، صدوق يهم، ثم قال بعد سرد أقوال النقاد فيه: قلت: هو حسن الحديث(")، وقال عنه في السير: عاصم بن بهدلة ليس بالقوي(؛)، وآخر أقواله فيه أنه:

والذي يترجح: أن عاصم بن بهدلة حجة إمام في القر اءة، وأمّا في الحديث فهو على ثلاثة أحوال: فإن روى عن شيوخه الذين لازمهم واختصّ بهم، وأتقن حديثهم، كأبي وائل، وزرّ بن حبيث، فئ فحديثه صحيح، ومن هذا ماخرجا له في الصحيحين، قال ابن حجر : ما له في الصحيحين سوى حديثين كلاهما من روايته عن زر بن حبيث عن أبي بن كعب قرنه في كل منهما بغيره، وله في البخاري موضع آخر معلق في الفتن(")، وإن روى عن غيرهم من شيوخه فحديثه حسن إذا لم يخالف. فحديثه يدور بين الصحيح والحسن، فهو ثقة له أوهام يسيرة؛ وثّقه جمع من العلماء مع معرفتهم بأوهامه كما تقدم، وقد رمز له ابن حجر في لسان الميزان بالرمز (صح)(V)، وهم ممن تُحُلِّم فيه بلا حجة، وقال في سند حديث أحد رجاله عاصم: هذا إسناد صحيح (^)، والله أعلم.

(1) ديوان الضعفاء (Y - (Y). (ז) الكاشف / / 11 (11. (r) ميزان الاعتدال r / /

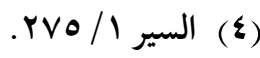

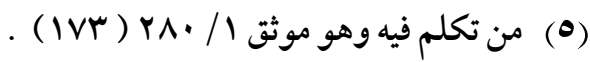

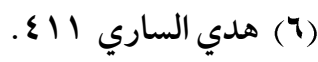

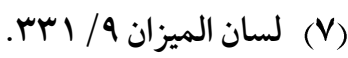

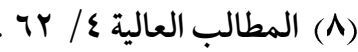


هو: أبو صالح عبد الله بن صالح الجهني المصري، كاتب الليث بن سعد، مشهور باسمه وكُنيته (1". روى عن: الليث، ومعاوية بن صالح، وموسى بن عُلي، وعبد الحميد بن بهر ام، وغيرهم (َ). روى عنه: إبراهيم بن الحسين الهمذاني، وإبراهيم الجوزجاني، وأبو الأزهر النيسابوري

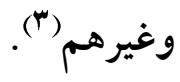

أقوال الأئمة فيه:

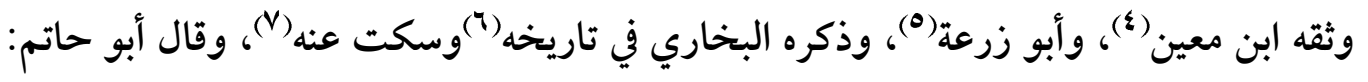
مصري صدوق أمين (^)، وقال ابن أبي حاتم: سمعت أبي يقول: سمعت عبد الملك بن شعيب بن الليث يقول: أبو صالح كاتب الليث ثقة مأمون، قد سمع من جدي حديثه، وكان يحدّث بحضرة أبي، وأبي يحضّه على التحديث(9). وقال عنه أحمد: كان أول أمره متماسكا ثم فسد بأخرة، وليس هو بشيء(·"()، وقال ابن حبان: منكر

(1) تهذيب الكمال سr/ 10 ( (V) ) . (Y) تهذيب الكمال 91/10 (דسMr) .

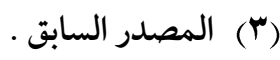

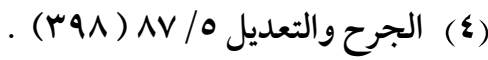

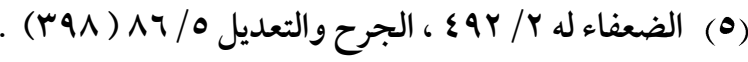

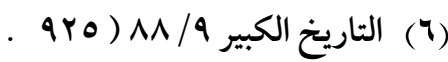

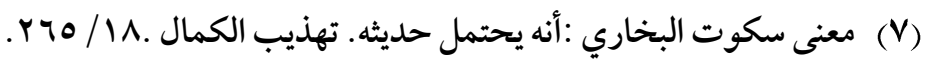

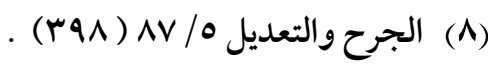
(9) المصدر السابق.

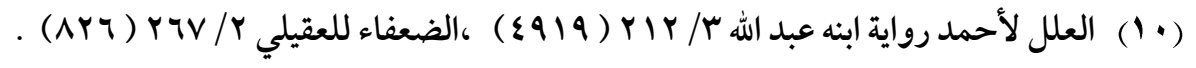




\section{الرواة الدين ضغفه الدمبي ثم وثقهم في كتابه (من تكلم فيه وهو موثقة)}

الحديث جدا(')، وقال النسائي: ليس بثقة(؟)، وقال علي بن المديني: ضربت على حديثه وما أروي عنه شيئا(")، وقال ابن حجر : صدوق كثير الغلط، ثبْت في كتابه، وكانت فيه غفلة(\&). موقف الذهبي منه: ذكره في ديوان الضعفاء وفي الكاشف ونقل أقوال النقّاد السابقة فيه ولم يُعَلِّق بشيء(ه)، وقال في المغني: مكثر، صالح الحديث، له مناكير، والصحيح أن البخاري روى عنه في الصحيح، وروى عنه ابن معين(')، وقال في الميزان: صاحب حديث وعلم، مكثر، وله مناكير (V)، وآخر أقو اله فيه أنه: صالح الحديث، له مناكير (^).

والذي يتزجح: أن أحاديثه الأولى مستقيمة، ثم تغيّر بأخرة؛ وعليه فالتي يرويها عنه الحذاق أمثال البخاري وأبي زرعة وأبي حاتم فهي صحيحة، وما يرويها غيرهم يتوقف فيها؛ قال ابن حجر: قلت: ظاهر كلام هؤ لاء الأئمة أن حديثه في الأول كان مستقيما، ثم طر أ عليه فيه تخليط، فمقتضى ذلك أن ما يجيء من روايته عن أهل الحذق كيحيى بن معين والبخاري وأبي زرعة وأبي حاتم فهو من صحيح حديثه، وما يجيء من رواية الشيوخ عنه فيتوقف فيه، والأحاديث التي رواها البخاري عنه في الصحيح بصيغة: حدثنا، أو: قال لي، أو: قال، المجردة قليل (9)، وقال في اللسان: الجمهور على تضعيفه، وكان البخاري حسَنُ الرأي فيه؛ إلا أنه كان كثير التخليط، والبخاري يعرف صحيح

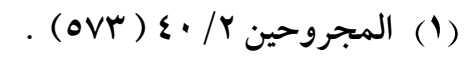

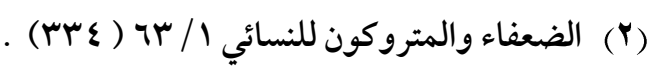

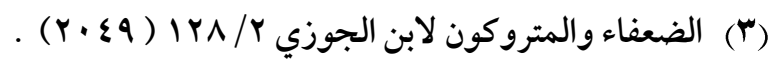

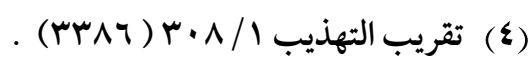

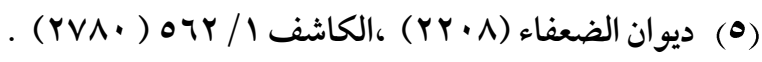

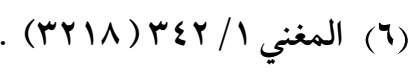

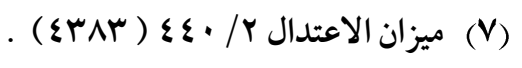

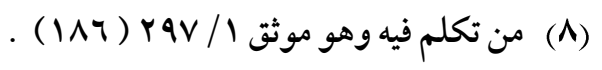

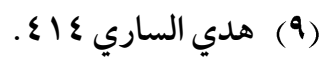


حديثه من سقيمه، فلا يغترّ بروايته عنه(1)، وقد حسّن له ابن حجر حديثان(")، والله أعلم. تذييل: قال ابن حجر في الهدي في معرض كلامه عن هذا الراوي: لقيه البخاري وأكثر عنه، وليس هو من شرطه في الصحيح، وإن كان حديثه عنده صالحًا، فإنه لم يورد له في كتابه إلا حديثًا واحدًا، وعلق عنه غير ذلك على ما ذكر الحافظ المزي وغيره، و كلامهم في ذلك متعقب بما سيأتي، وعلق عن الليث بن سعد شيئًا كثيرًا كله من حديث أبي صالح عن الليث. ثم ساق ابن حجر تسعة أحاديث من ذلك، ثم قال: وأما التعليق عن الليث من رواية عبدالله بن صالح عنه فكثير جدًا، وقد عاب ذلك الإسماعيلي على البخاري، وتعجب منه كيف يحتج بأحاديثه حيث يعلقها! فقال: هذا عجيب، يحتج به إذا كان منقطعًا ولا يحتج به إذا كان متصلًا! وجواب ذلك: أن البخاريّ إنما صنع ذلك لما قررناه أن الذي يورده من أحاديثه صحيح عنده قد انتقاه من حديثه؛ لكنه لا يكون على شرطه الذي هو أعلى شروط الصحة، فلهذا لا يسوقه مساق أصل الكتاب، وهذا اصطلاح قد عرف بالاستقر اء من صنيعه، فلا مشاحّة فيه، والله أعلم (َ). 


\section{الرواة الدين ضعفهم الدهبي ثم وثقهم في كتابه: (من تكلسم فيه وهو موثق) )}

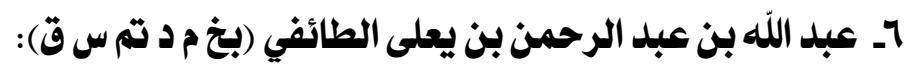
هو: عبد الله بن عبد الرحمن بن يعلى بن كعب الطائفي، أبو يعلى الثقفي.

روى عن: عبد الله بن الحكم الثقفي، وعبد ربه الثقفي، وعبد الرحمن بن القاسم، وغيرهم (1). روى عنه: سفيان الثوري، وعبدالله بن المبارك، وابن مهدي، وأبو نعيم، وغيرهم(").

وثقـه ابـن المـديني (")، والعجلـي (\&)، وذكـره ابـن حبـان في الثقـات(ه)، وقـال ابـن معسين: لـيس بـه بـأس يكتـب حديثه، وقـال مـرة: صـويلح، وقـال مـرة: ضسعيف(ه)، وقـال الـدارقطني: يعتبـر بـهـ (V)، وقـال ابـن عـدي: أحاديثـه مسـتقيمة وهـو ممسن يكتـب حديثـه(^)، وقـال البخـاري: فيـه

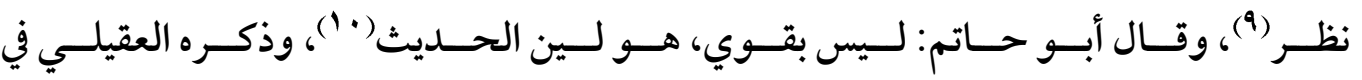

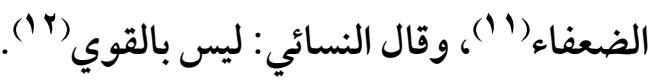

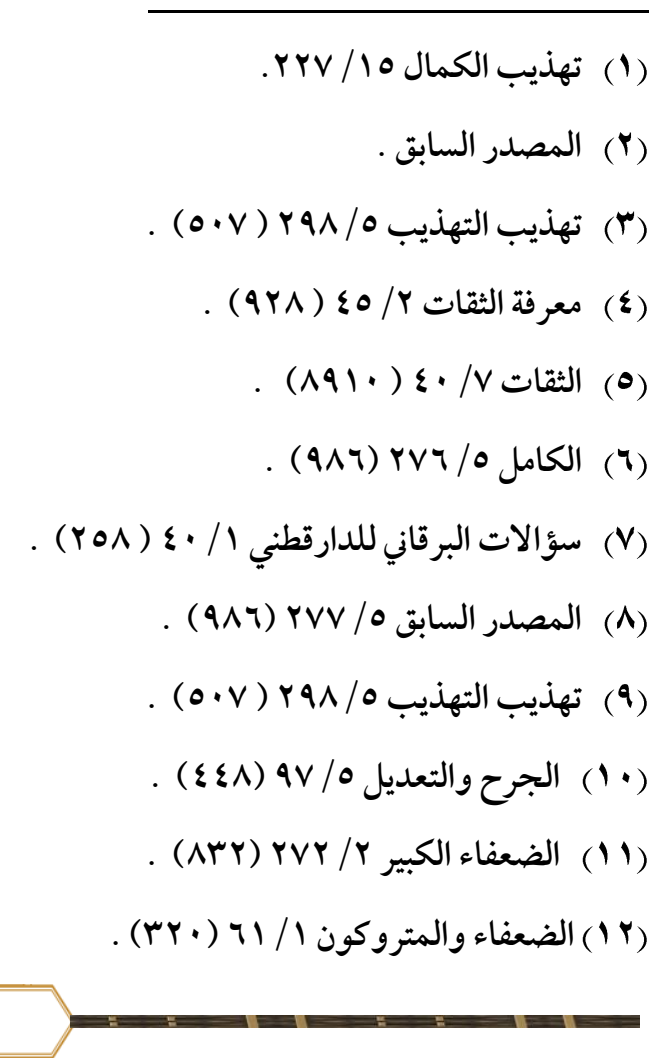




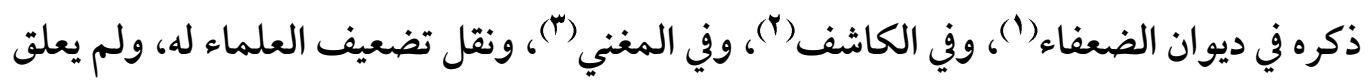
بشيء، ثم ذكره في كتابه من تكلم فيه وهو موثق (๕). والذي يترجح: أنه صدوق يخطي، فنقبل من حديثه ماوافق فيه الثقات، وقد أخرج له مسلم حديثا

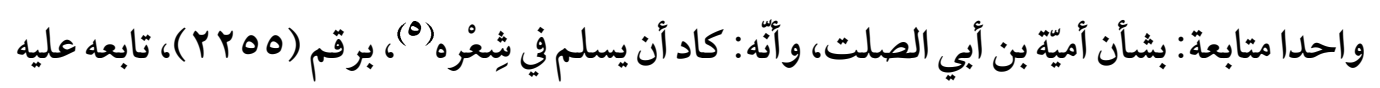
إبر اهيم بن ميسرة عنده، وقال ابن حجر عنه: صدوق يخطئ ويهم(")، وقد رمز له في آخر اللسان بـ(هـ) : وهم المختلف فيهم والعمل على توثيقهم (v)، والله أعلم.

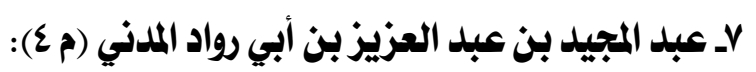

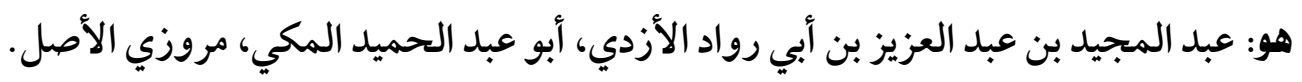
روى عن: أبيه، وعبد الملك بن جريج، وكان أعلم الناس بحديثه، والليث بن سعد، وغيرهم (ه). روى عنه: أحمد بن حنبل، والزبير بن بكار، والحميدي، وغيرهم (9).

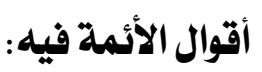
وثقه ابن معين(·)"، وقال عنه أحمد: ثقة ليس به بأس('")، وقال البخاري: يرى الإرجاء، وكَانَ

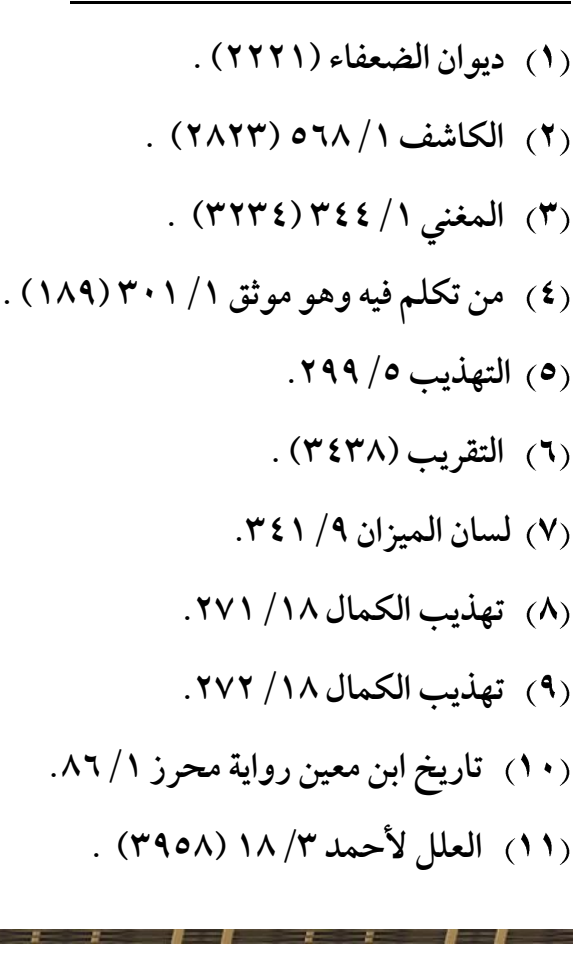




\section{(من تكلم فيه وهو موثقة) \\ الحميدي يتكلم فيه(')، وقال أبو داوود: ثقة داعية إلى الإرجاء(').}

وقال أبو حاتم: ليس بالقوي، يكتب حديثه،كان الحميدي يتكلم فيه(")، وقال ابن حبان: متروك(")، ليس بالقوي، وقال ابن سعد: مرجئ ضعيف، وقال يحيى بن سعيد: كذاب(•). موقف الذهبي منه:

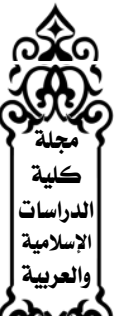

ذكره في ديوان الضعفاء(آ)، وفي الكاشف(V)، وفي المغني (^)، ونقل أقوال النقاد فيه ولم يعلق بشيء، وقال في السير: وكان من المرجئة(9)، وقال في الميزان: صدوق مرجئ كأبيه(·()، وآخر كلامه فيه: ثقة مرجئ داعية(1) (1')

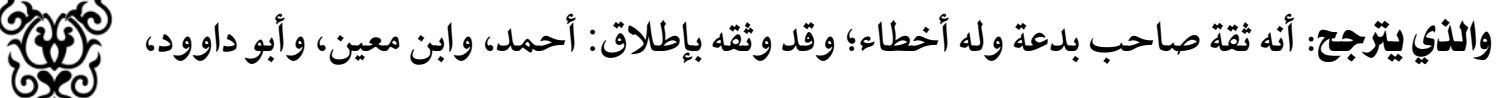
والنسائي، والخليلي مع علمهم بأنه مرجئ داعية؛ وقال الدارقطني: كان أثبت الناس في ابن جريح (r)"، قال ابن حجر : صدوق يخطئ، وكان مرجئا، أفرط ابن حبان فقال متروك (rا')، ورمز له

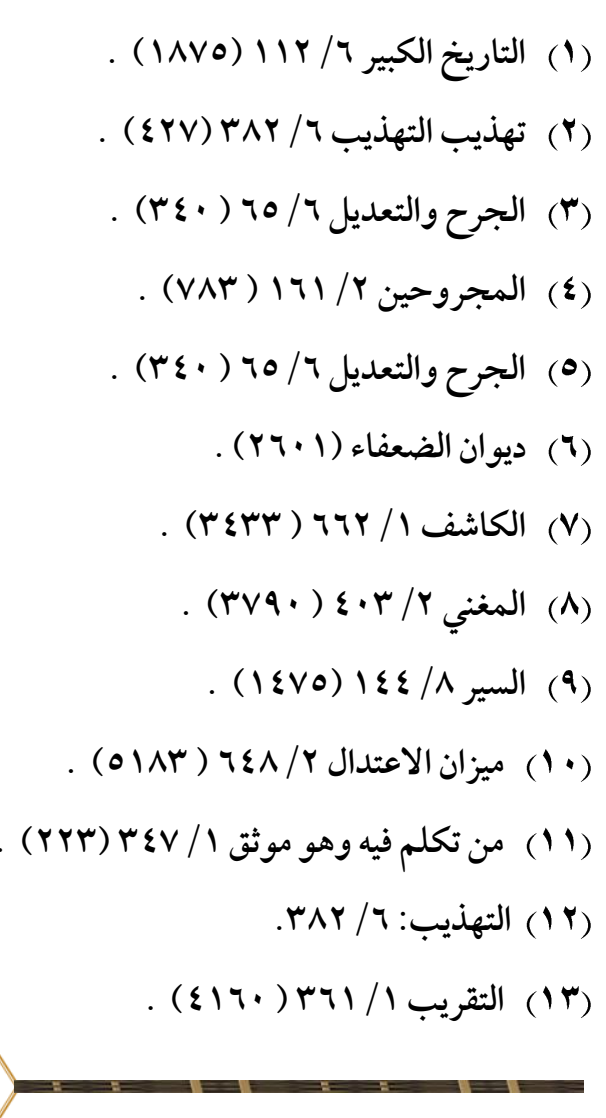


في آخر اللسان بـ(هـ): وهم المختلف فيهم والعمل على توثيقهم(")، روى له مسلم مقرونًا

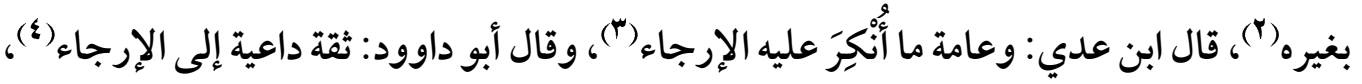
فأمّا مذهبه الرديء؛ فقد قال علي بن المديني: قلت ليحيى ـ يعني القطان ـ إن عبد الرحمن ـ يعني

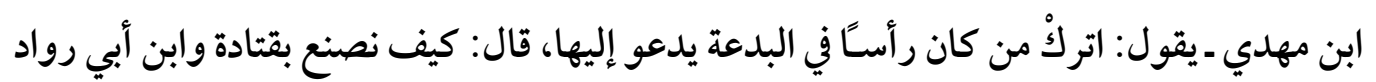
وعمر بن ذر؟! وذكر قومتا، قال يحيى: إنْ تركَ هذا الصنف ترك ناستا كثيراً (•)، وقد أخرج البخاري ومسلم عن جماعة قيل عنهم إنهم دعاة(7)، والله أعلم.

هو: عبد الملك بن أعين الكوفي أخو بلال، وحمران، وزرارة، وعبد الأعلى، مولى بني شيبان(v).

يـ عبد الملك بن أعين (ع): روى عن: أبي وائل شقيق بن سلمة، وعبد الله بن الهاد، وأبي عبد الرحمن السلمي، وغيرهم. روى عنه: إسماعيل بن سميع، والسفيانان، وغيرهم (^).

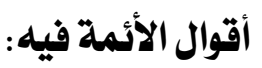
قال عنه أبو حاتم: مِن عُتَّق الشيعة، محله الصدق، صالح الحديث، يكتب حديثه(9)، وقال

(1) (1) لسان الميزان / آبT.

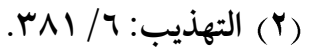

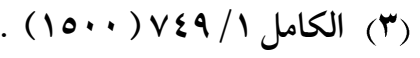

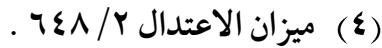

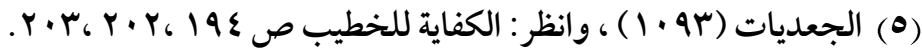

$$
\begin{aligned}
& \text { (ד) محاسن الاصطلاح Tr9. }
\end{aligned}
$$

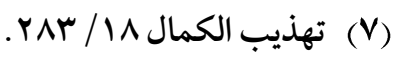

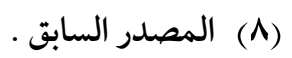

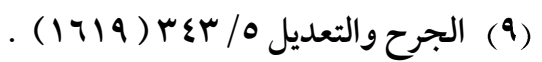




\section{الرواة الدين ضعفهم الدهبي ثم وثقهم في كتابه :(من تكلم فيه وهو موثق)}

البخاري: وكان شيعيا... يحتمل في الحديث(')، وذكره ابن حبان في الثقات، وقال: وكان يتشيع (؟)،

ووثقه العجلي (“) - (ب)

وقال ابن معين: ليس بشيء()، وقال ابن عيينة: كان رافضيًا صاحب رأي (ه)، وذكره العقيلي في الضعفاء(").

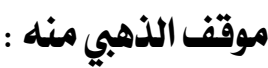
قال عنه في ديوان الضعفاء: ثقة(ل)، وقال في الكاشف: شيعي صدوق (^)، وقال في المغني: روى له البخاري مقرونا بآخر، وهو شيعي(9)، ونقل في الميزان أقوال النقاد ولم يعلق بشيء(·")، وآخر قوله فيه: صدوق. (1) والذي يترجح: أنه شيعي صدوق، وهذا هو الذي ذكره الذهبي هنا، وكذا ابن حجر في التقريب، وزاد: شيعي، ثم قال: له في الصحيحين حديث واحد متابعة(ז')، ورمز له في آخر اللسان بـ(صح):

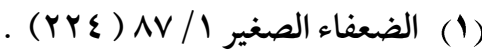
( (

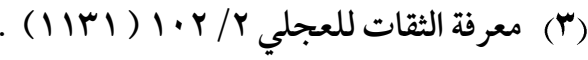

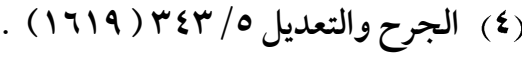

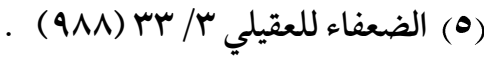

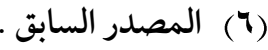

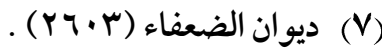

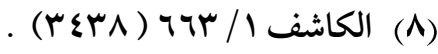

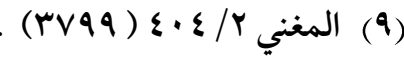
(1.) ميزان الاعتدال / / / (19 (019).

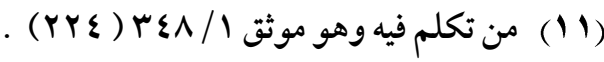

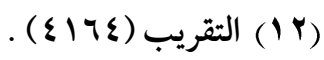


وهم ممن تكلم فيه بلا حجة"(') و والله أعلم.

\section{9ـ عبد الواحد بن زياد (َ) (ع):}

هو: عبد الواحد بن زياد العبدي، مولاهم، أبو بشر، وقيل أبو عبيدة البصري.

روى عن: الأعمش، وحجاج بن أرطاة، وسعيد بن إياس، وغيرهم (َّ).

روى عنه: إبر اهيم بن الحجاج، وعبد الرحمن بن مهدي، وعبد الواحد بن غياث، وغيرهم (\&). أقوال الأئمة فيه:

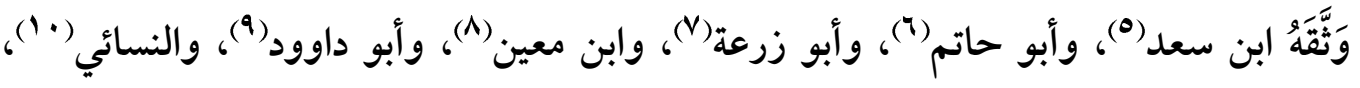

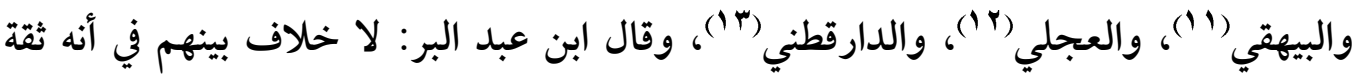

(1) لسان الميزان / / آبr.

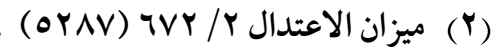

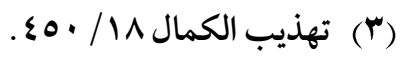

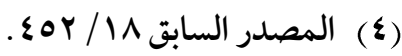

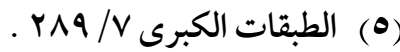

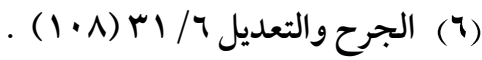

(V)

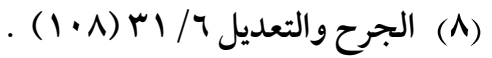

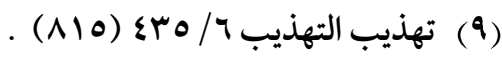

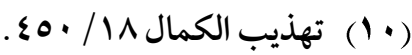

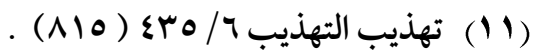

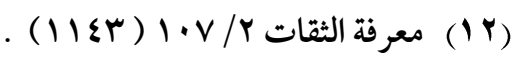

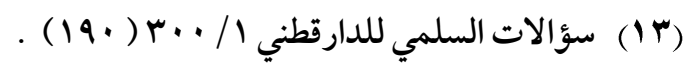

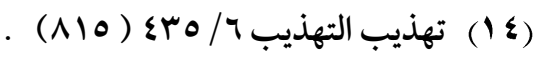




\section{الرواة الدين ضقفهم الدهيي ثم وثقهم في كتابه :(من تكلم فيه وهو موثق)}

وقال ابن المديني: كنت أذاكره بحديث الأعمش فلا يعرف منه حرفا(')، وقال ابن حجر تعليقا على قول ابن المديني: قلت وهذا غير قادح، لأنه كان صاحب كتاب، وقد احتّج به الجماعة(َ). موقف الذهبي منه:

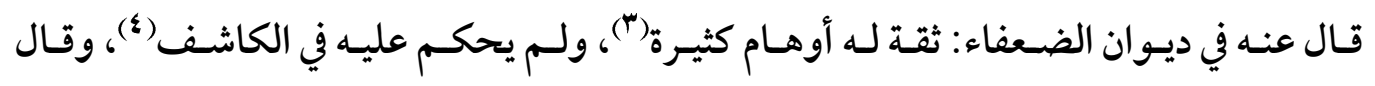

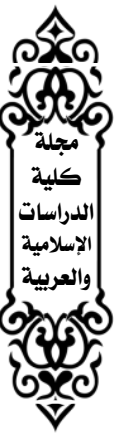

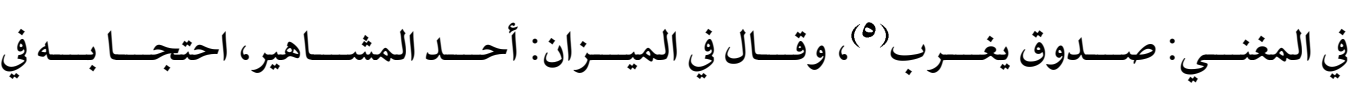

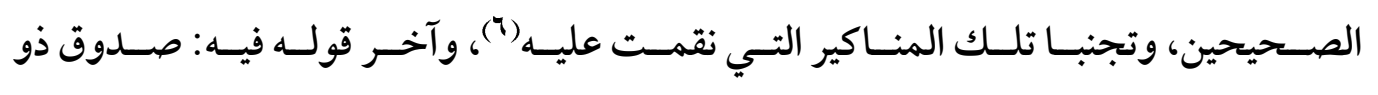

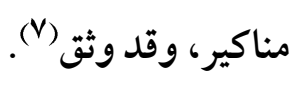
والذي يترجح:

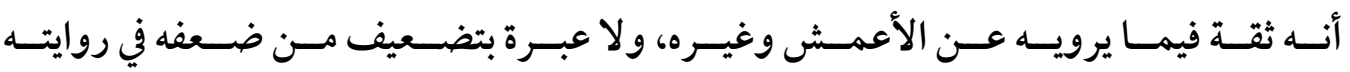

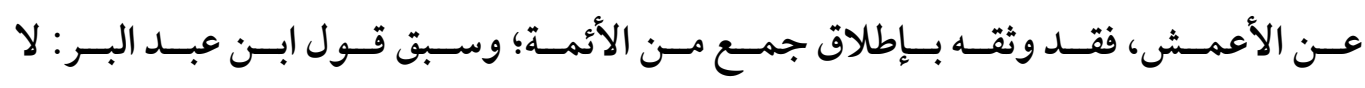

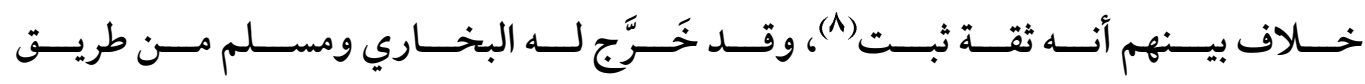

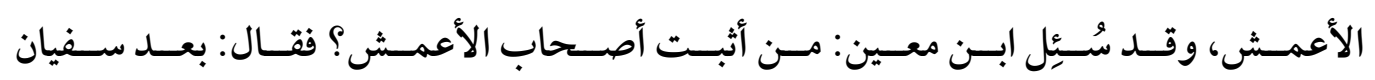

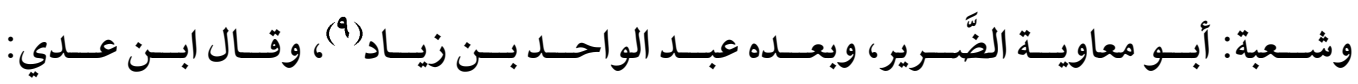

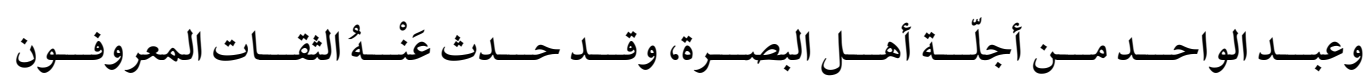

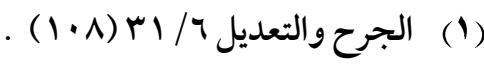

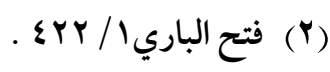

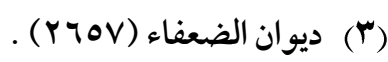

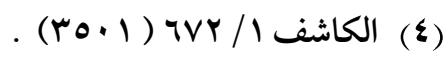

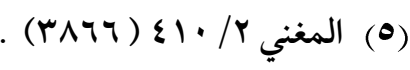

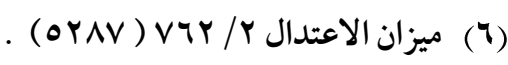

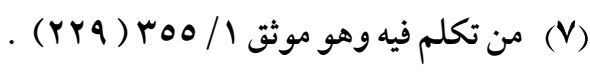

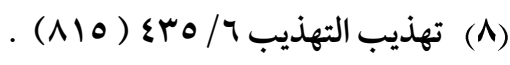

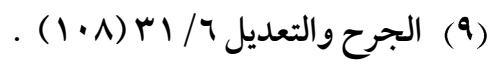




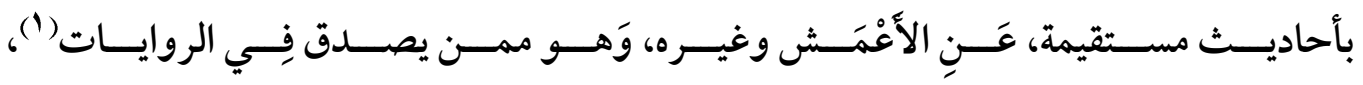

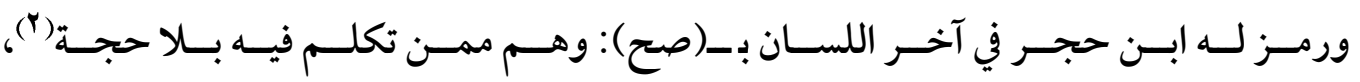
و الله أعلم.

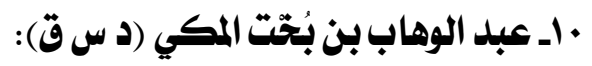
هو : عبد الوهاب بن بُخْت (ب) الأموي أبو عبيدة، سكن الشام، ثم تزوج بالمدينة، وأقام بها.

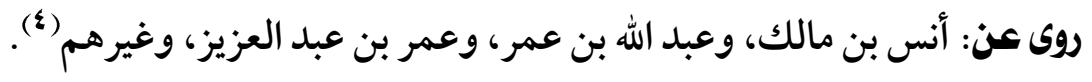
روى عنه: أيوب السختياني، ومالك بن أنس، ويحيى بن سعيد الأنصاري، وغيرهم (ه). أقوال الأئمة فيه:

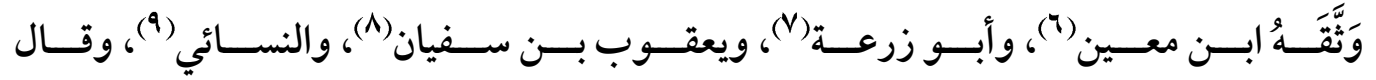

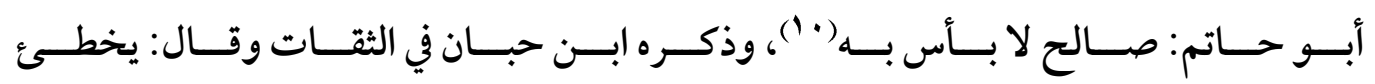

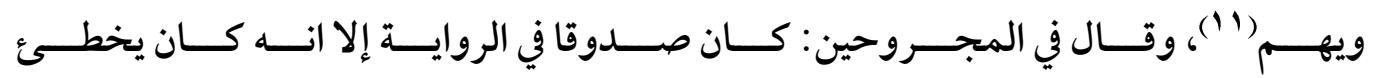

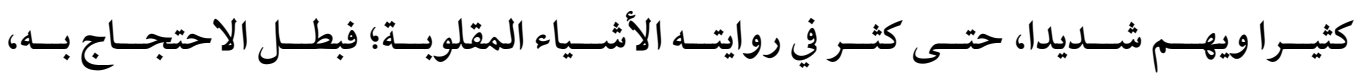

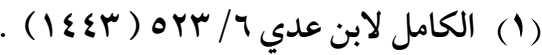

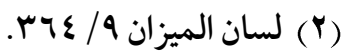

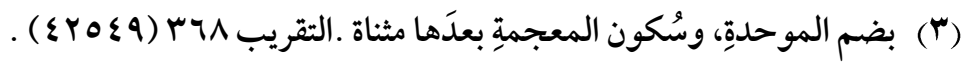

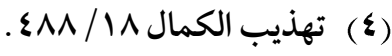

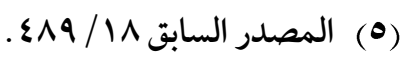

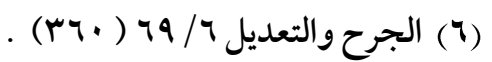
. المصدر السابق (V)

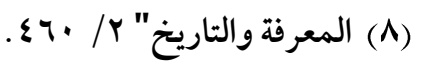

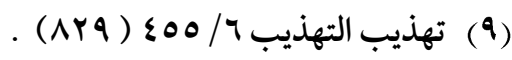

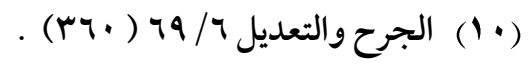

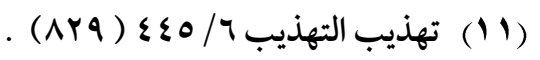




\section{الرواة الدين ضقفهم الدهبي ثم وثقهم في كتابه :(من تكلم فيه وهو موثق)}

$$
\text { موقف يحيى بن معين حسن الر أي فيه('). }
$$

قال عنه في ديوان الضعفاء: ثقة كثير الوهم(")، وسكت عنه في الكاشف(")، وقال عنه في المغني: صدوق في أحاديثه أوهام كثيرة( )، وقال عنه في الميزان: كثير الأوهام(ه)، واستقرّ قوله على أنه: ثقة

والذي يترجح: أنه ثقة، فقد وَثَّقَهُ جمع من كبار الأئمة القدماء، وقد قرر الحافظ في التقريب توثيقه(V)، وعليه فلا التفات لمن جرحه بلفظ عام غير مفسر، كابن حبان وأبي حاتم في مقابل الجمع الذين وثقوه، حسب ما قررته قواعد الجرح والتعديل عند النقاد، والله أعلم.

I ـ عبد الوهاب بن عطائ الخفاف (عخ م ع): هو: عبد الوهاب بن عطاء الخفاف، أبو نصر العجلي، مولاهم، البصري، سكن بغداد. روى عن: حميد الطويل، وخالد الحذاء، وشعبة بن الحجاج، وغيرهم(A). روى عنه: أحمد بن حنبل، وابن معين، وإسحاق بن راهويه، وغيرهم(9).

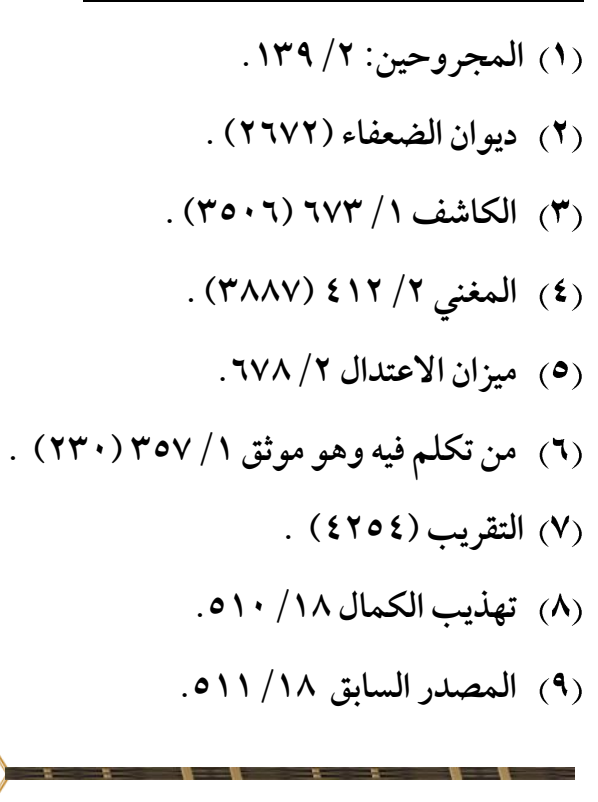


وثقه الدارقطني (1)، والحسن بن سفيان، وصالح بن محمد الأسدي، وذكره ابن حبان في الثقات(؟)، وقال ابن معين: ثقة، ومرة قال: لا بأس به، يكتب حديثه(")، وقال ابن عدي، والنسائي: ليس به بأس(๕)، وقال ابن سعد: كان كثير الحديث معروفا، صدوقا إن شاء الله(•)، وقال أحمد: من أعلم الناس بحديث ابن أبي عروبة، ومرة قال: ضعيف(")، وقال أحمد: كان يحيى بن سعيد حسن الر أى في عبد الوهاب الخفاف، وكان يعرفه معرفة قديمة(V)، وقال أبو حاتم: يكتب حديثه، محله الصدق(^)، وأنكروا عليه حديثًا في فضل العباس وولده(9)، وذكره أبوزرعة في الضعفاء(•"). موقف الذهبي منه:

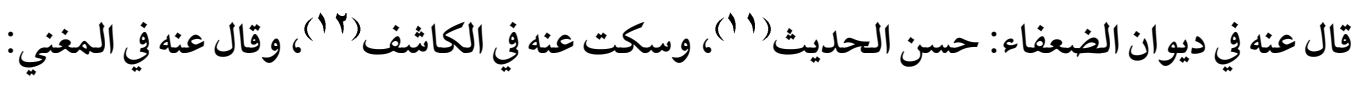
ضعفه أحمد وقواه غيره(r(1)، وقال عنه في الميزان: صدوق(\&)، واستقرّ قوله على أنه: صدوق

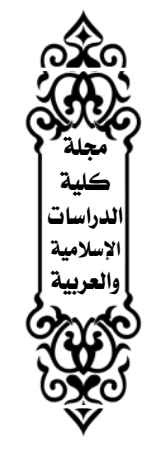

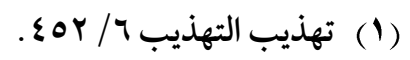

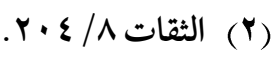

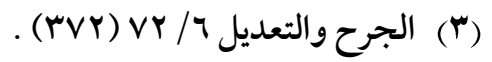

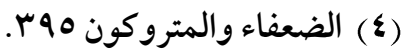

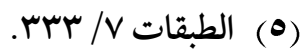

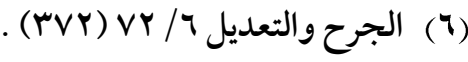
. (V) العلل (rory) (^) (9) تاريخ بغداد: $11 /$ /

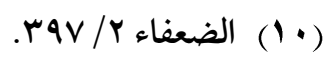

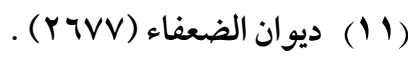

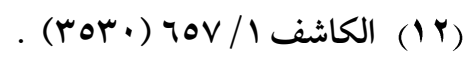

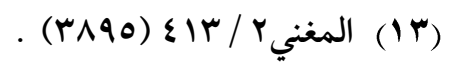

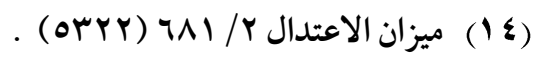




\section{الرواة الدين ضعفهم الدهبي ثم وثقهم في كتابه: (من تكلم فيه وهو موثقة)}

وثق (')

والذي يتزجح: أنه صدوق حسن الحديث، وهذا مستفاد من أقوال النقاد فيه، وروايتهم عنه؛ أمثال أحمد، وابن معين، قال البزار: عبد الوهاب ليس بالقوي في الحديث، وقد روى عنه أهل العلم (َ)، ولا يضره الخطأ في حديث أو حديثين، قال ابن حجر : صدوق ربما أخطأ، أنكروا عليه حديثا في

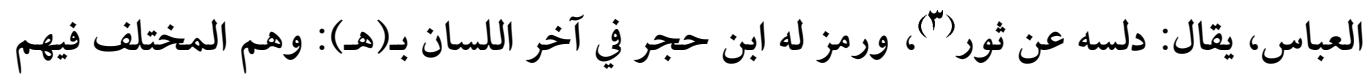
والعمل على توثيقهم (๕)، والله أعلم.

rا بعبيد اللّه بن موسى العبسي الكوفي (ع):

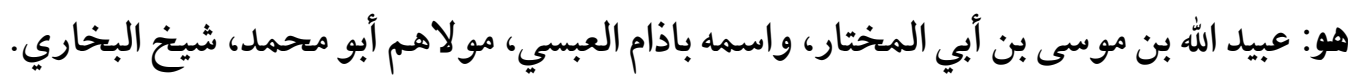
روى عن: أسامة بن زيد الليثي، وإسر ائيل بن يونس، وزائدة بن قدامة، وغيرهم (ه). روى عنه: البخاري، وإسحاق، وابن معين، وأحمد بن حنبل، وغيرهم (ج).

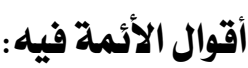
وثقه أبو حاتم (V)، وابن سعد (^)، والعجلي (9)، وذكره ابن حبان في الثقات(· (م)، وقال أبوداوود: جاز

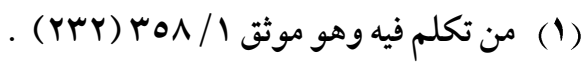

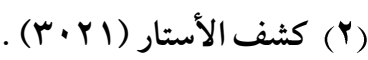

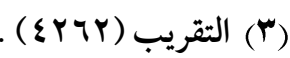

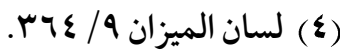
(0) تهذيب الكمال 190/19.

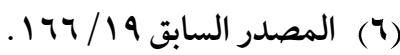

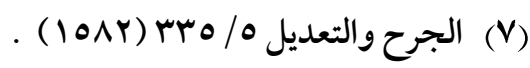

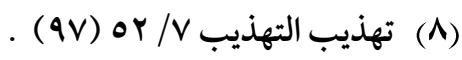

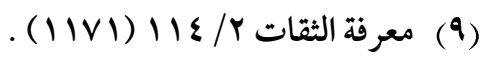

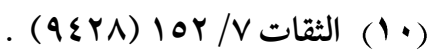


حديثه، وقال أحمد: صاحب تخليط(')، وقال يعقوب الفسوي: منكر الحديث("). موقف الذهبي منه: قال عنه في ديوان الضعفاء: ثقة كرهه بعضهم لفرط تشيعه(")، وقال عنه في الكاشف: الحافظ أحد الأعلام على تشيعه وبدعته (\&)، وقال عنه في المغني: ثقة شيعي متحرق لم يرو عنه أحمد لذلك(•)، وقال عنه في الميزان: ثقة في نفسه، لكنه شيعي متحرق (")، واستقرّ قوله على أنه: ثقة؛ لكنه شيعي جلد، كره بعضهم الأخذ عنه (v).

والذي يترجح: أنه ثقة متشيع؛ قال الذهبي في السير : الإمام الحافظ العابد(^)، وقال في تذكرة الحفاظ: الحافظ الثبت(9)، وقال ابن حجر في الفتح: عبيد الله بن موسى من كبار شيوخ البخاري، سمع من جماعة من التابعين، وثقه ابن معين، وأبو حاتم، والعجلي، وعثمان بن أبي شيبة، وآخرون، وقال

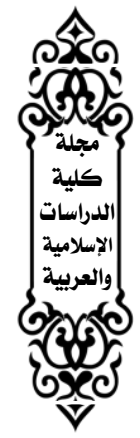
ابن سعد: كان ثقة صدوقا حسن الهيئة، وكان يتشيع، ويروي أحاديث في التشيع منكرة، وضعف بذلك عند كثير من الناس، وعاب عليه أحمد غلوه في التشيع، مع تقشفه وعبادته، وقال أبو حاتم: كان أثبتهم في إسرائيل، وقال ابن معين: كان عنده جامع سفيان الثوري، و كان يستضعف فيه، قلت:

$$
\begin{aligned}
& \text { (1) العلل 90/1 (Y) (1) . }
\end{aligned}
$$

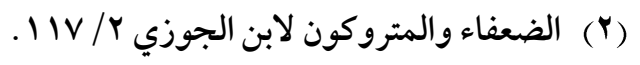

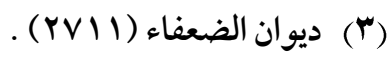

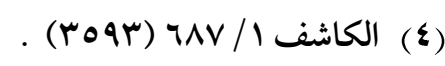

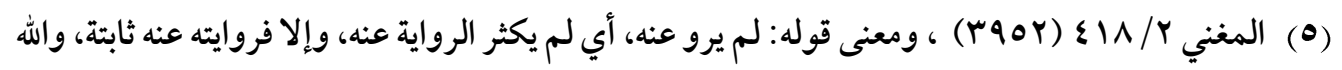

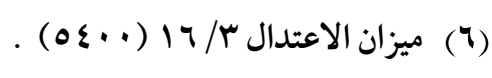

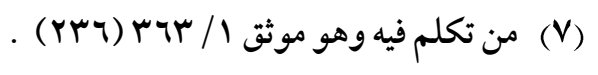

$$
\text { rIV/A }(\Lambda)
$$

(q) تذكرة الحفاظ / / 


\section{الرواة الدين ضعفهم الدهيي ثم وثقهم في كتابه: (من تكلم فيه وهو موثق)}

لم يخرج له البخاري من روايته عن الثوري شيئا، واحتجّ به هو والباقون(')، والله أعلم.

با_عطاء بن أبي مسلم عبد الله الخراساني (ع): هو: عطاء بن أبي مسلم الخراساني، أبو أيوب، نزيل الشام، مولى المهلب بن أبي صفرة الأزدي.

روى عن: عبد الله بن عباس، وأنس بن مالك مرسلا، والحسن البصري، وغيرهم (َ).

روى عنه : حماد بن سلمة، وسفيان الثوري، وشعبة بن الحجاج، وغيرهم (").

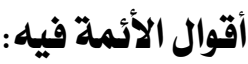

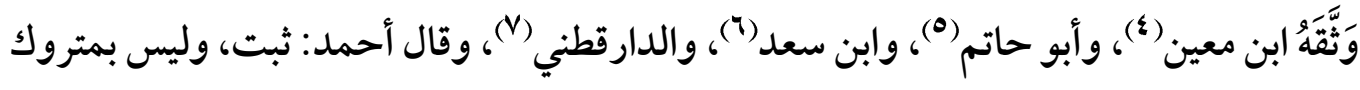
الحديث(^)، وقال النسائي: ليس به بأس(")، وقال ابن عدي: أرجو ألا بأس به(·')، وذكره البخاري

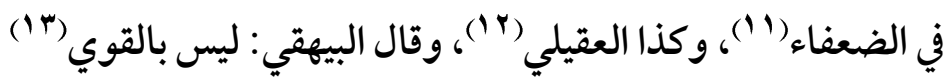

$$
\begin{aligned}
& \text { (1) فتح الباري / / / ع . }
\end{aligned}
$$

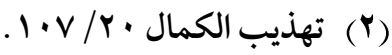

$$
\begin{aligned}
& \text { (ץ) المصدر السابق • ^/ • • 1. }
\end{aligned}
$$

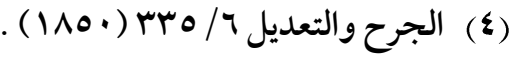
(•) (•) المصدر السابق.

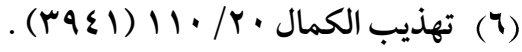

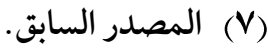

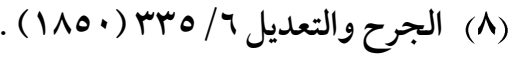

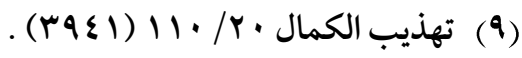

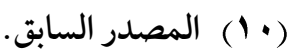

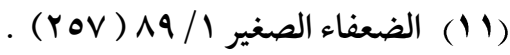

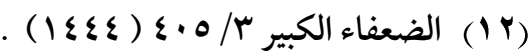

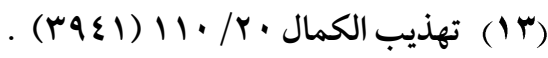




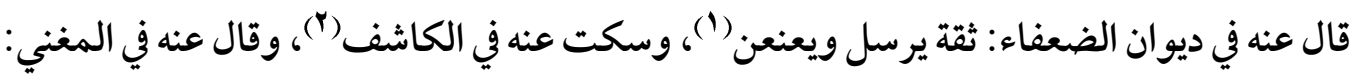

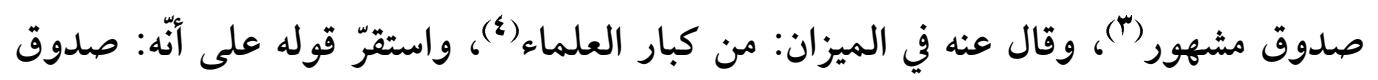

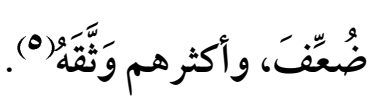

والذي يترجح: أنه ثقة له أوهام، فقد وثّقه جهابذة النقّاد؛ قال الترمذي في العلل الكبير: وعطاء الخراساني رجل ثقة، روى عنه الثقات من الأئمة مثل مالك ومعمر وغيرهما، ولم أسمع أن أحدا

$$
\text { من المتقدمين تكلم فيه بشيء) }
$$

وقال ابن رجب في شـرح العلل : وعطاء الخر اســاني، بالرغم من أن البخاري جعل عامة أحاديثه مقلوبة، ونعته بالضعف، إلا أن بقية العلماء احتجوا بحديثة الخالي من الوهم والخطأ، وروى عنه مسـلم و أصسحاب السـنن الأربعة، وقد وثقه ابن معين، وقال ابن أبي حاتم عن أبيه: ثقة صـدوق، قلت يحتج به؟ قال: نعم، وقال النسائي: ليس به بأس، وقال الدارقطني: ثقة في نفسه، وتوثيق هذا العدد الغفير له يدفع رأي البخاري فيه؛ ومع هذا الدفع تبقى لعطاء أوهامه وعلله(V)، ثم قال في موضـع آخر : وقد بيّن الترمذي في علله أن ما ذكره البخاري لا يوافق عليه، وأنه ثقة عند أكثر أهل الحليث، قال: ولم أسـمع أن أحداً من المتقدمين تكلم فيه (^)، ثم قال ابن رجب: وأم أما الحكاية عن سـعيد بن المسـيب أنه كذّبه فيما رُوي عنه، فلا تثبت، وقد كذّب ابن المسـيب عكرمة، ولم

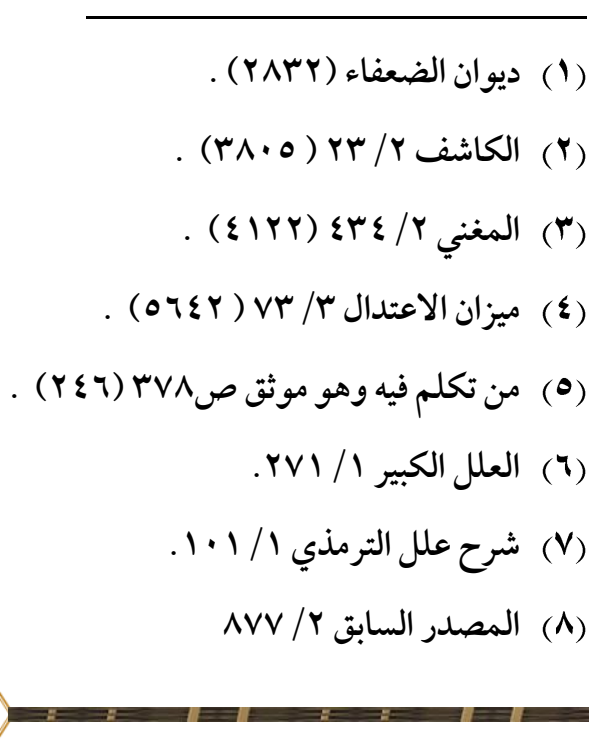




\section{الرواة الدين ضعفهم الدهبي ثم وثقهم في كتابه :(من تكلم فيه وهو موثقة)}

يتر كه البخاري بتكذيبه، بل خَرَّج له، واعتذر عن تكذيب مَنْ كَذَّبه في كتاب القر اءة خلف الإمام وعن تكذيب مالك لابن إسحاق ...، وعطاء الخر اساني أحقّ أن يعتذر عما قاله ابن المسيب ــ إن صحَّ - فإنّه أعظم وأجلّ قدراً من عكرمة، بل لا نسبة بينهما في الدين والورع (1)، وقد رمز له ابن حجر في آخر اللسان بـ(هـ): وهم المختلف فيهم والعمل على توثيقهم(؟)، والله أعلم.

عا_عطاء بن أبي ميمونة (خ م د س ق) : هو: عطاء بن أبي ميمونة، واسمه منيع البصري، أبو معاذ مولى أنس بن مالك. روى عن: أنس بن مالك، وجابر بن سمرة، والحسن البصري، وعمران بن حصين، وغيرهم (َّ). روى عنه: شعبة، وحماد بن سلمة، وخالد الحذاء، وغيرهم (\&).

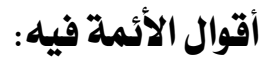

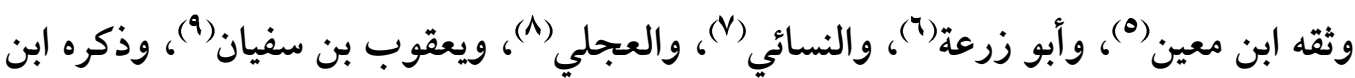

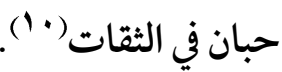

$$
\begin{aligned}
& \text { (1 (1) شرح علل الترمذي Y / وما بعدها }
\end{aligned}
$$

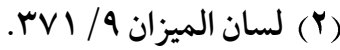

$$
\begin{aligned}
& \text { IIV/Y • تهذيب الكمال } \\
& \text { ( }
\end{aligned}
$$

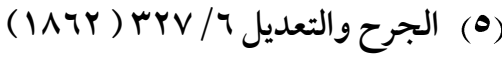

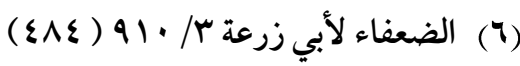$$
\text { IIV/r • تهذيب الكمال (V) }
$$

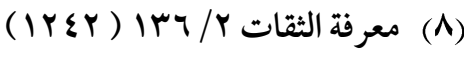

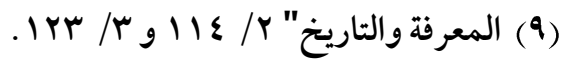

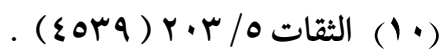


قال البخاري: كان يرى القدر (1)، وذكره أبو زرعة الرازي في الضعفاء("). موقف الذهبي منه: قال عنه في ديوان الضعفاء: مختلف فيه(")، وقال عنه في الكاشف: صدوق (\&) موقي وقال عنه في المغني: تابعي صدوق، وثقوه(•)، وقال عنه في الميزان: قلت: بل قدري صغير(")، واستقرّ قوله على أنه:

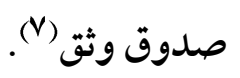

والذي يترجح: أنه ثقة يرى القدر؛ فقد احتج به الأئمة عدا الترمذي، قال الذهبي في السير : بصري، حجة(^)، وقال ابن حجر في الفتح: عطاء بن أبي ميمونة البصري أبو معاذ مولى أنس، وثقه ابن معين والنسائي وأبو زرعة، وقال ابن عدي: في أحاديثه بعض ما ينكر، وقال البخاري وغير واحد: كان يرى القدر، قلت: احتج به الجماعة سوى الترمذي، وليس له في البخاري سوى حديثه عن

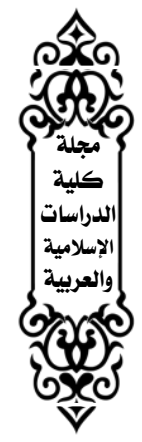
أنس، في الاستنجاء(9)، وقال في التقريب: ثقة رمي بالقدر (•)"، ورمز له في آخر اللسان بـ(هـ): وهم المختلف فيهم والعمل على توثيقهم (1")، والله أعلم.

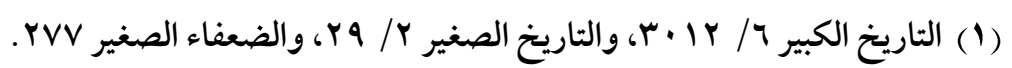

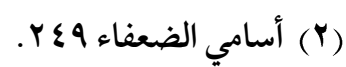

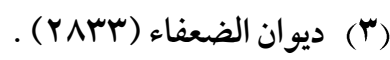
. ( ) (

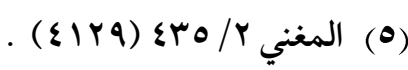

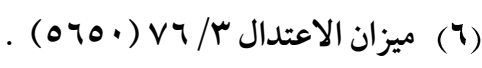

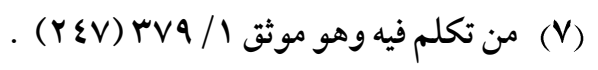

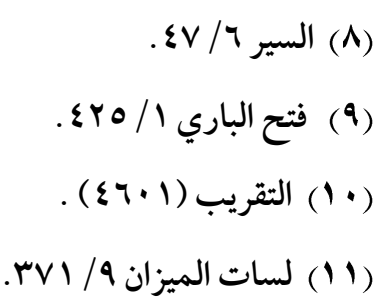


10 عكرمة مولى ابن عباس (ع ) :

هو: عكرمة القرشي الهاشمي، أبو عبد الله المدني، مولى عبد الله بن عباس (') . روى عن: علي بن أبي طالب، ومولاه عبد الله بن عباس، وعبد الله بن عمر، وعبد الله بن عمرو، ومعاوية بن أبي سفيان، وأبي سعيد الخدري، وأبي هريرة، وعائشة(؟)، وغيرهم، رضي الله عنهم. روى عنه: إبر اهيم النخعي ومات قبله، وأرطاة بن أبي أرطاة، وإسحاق بن عبد الله بن جابر العدني، وإسماعيل بن أبي خالد، وغيرهم (َ). أقوال الأئمة فيه:

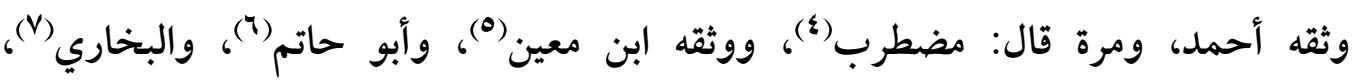

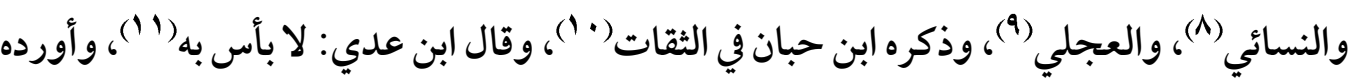
العقيلي في الضعفاء(r) .

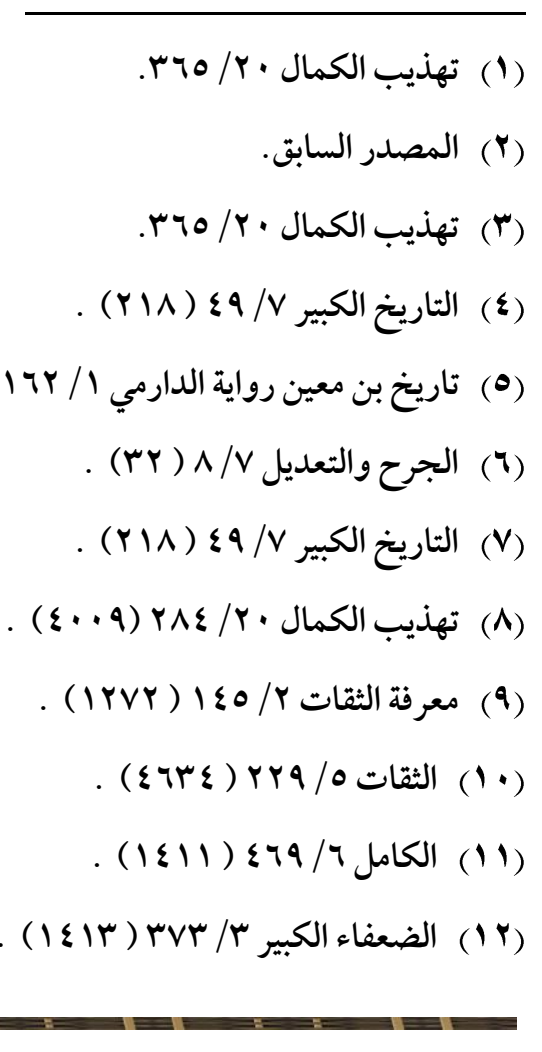


قال عنه في ديوان الضعفاء: ثقة ثبت(')، وقال عنه في الكاشف: ثبت؛ لكنه إباضي، يرى السيف، روى له مسلم مقرونا وتحايده مالك(؟)، وقال عنه في المغني (َ) وفي الميزان: أحد أوعية العلم،

تُكلم فيه لر أيه لا لحفظه فاتهم برأي الخوارج()، واستقرّ قوله على أنه: صدوق، حافظ عالم (•). والذي يترجح: أنه ثقة، والكلام الذي قيل فيه مردود، تعقبّه الأئمة ودفعوه بالحجة والدليل؛ قال ابن حجر : عكرمة أبو عبد الله مولى ابن عباس احتج به البخاري وأصحاب السنن، وتركه مسلم فلم يخرج له سوى حديث واحد في الحج مقرونا بسعيد بن جبير، وإنما تر كه مسلم لكلام مالك فيه، وقد تعقب جماعة من الأئمة ذلك، وصنفوا في الذبّ عن عكرمة، منهم أبو جعفر ابن جرير الطبري، ومحمد بن نصر المروزي، وأبو عبد الله ابن مندة، وأبو حاتم ابن حبان، وأبو عمر ابن عبد البر،

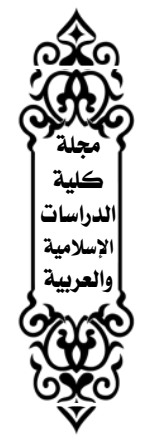
وغيرهم، وقد رأيتُ أن ألخصّ ما قيل فيه هنا، وإن كنت قد استوفيت ذلك في ترجمته من مختصري لتهذيب الكمال، فأمّا أقوال من وهاه فمدارها على ثلاثة أشياء: على رميه بالكذب، وعلى الطعن فيه بأنه كان يرى رأي الخوارج، وعلى القدح فيه بأنه كان يقبل جوائز الأمر اء، فهذه الأوجه الثلاثة

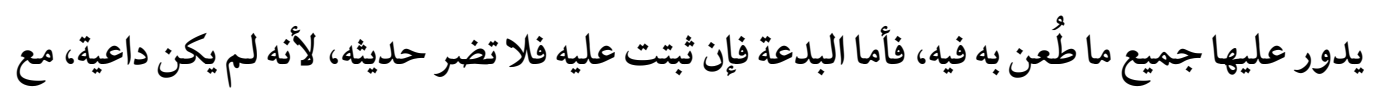
أنها لم تثبت عليه، وأما قبول الجوائز فلا يقدح أيضا إلا عند أهل التشديد، وجمهور أهل العلم على الجواز، كما صنف في ذلك ابن عبد البر، وأما التكذيب فسنبين وجوه رده بعد حكاية أقو الهم وأنه لا يلزم من شيء منه قدح في روايته..... ثم قال: وقال أبو عبد الله محمد بن نصر المروزي: أجمع عامة أهل العلم على الاحتجاج بحديث عكرمة، واتفق على ذلك رؤساء أهل العلم

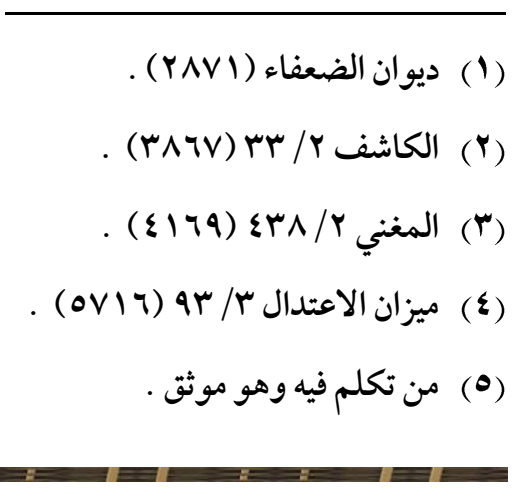




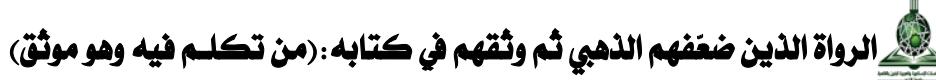

بالحديث، من أهل عصرنا، منهم: أحمد بن حنبل، وإسحاق بن راهويه، وأبو ثور، ويحيى بن

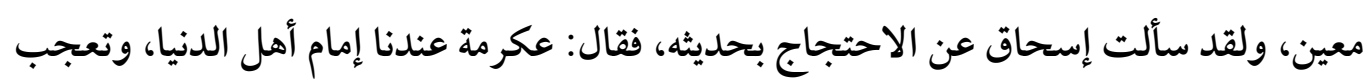

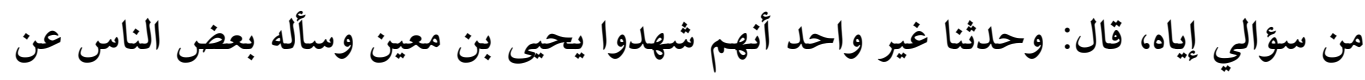

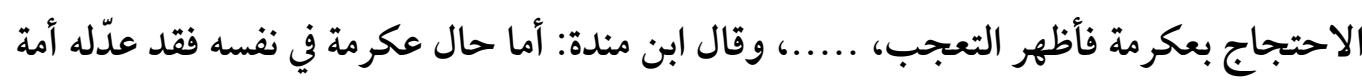

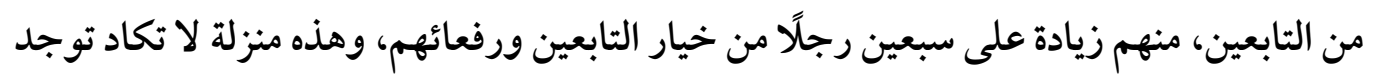

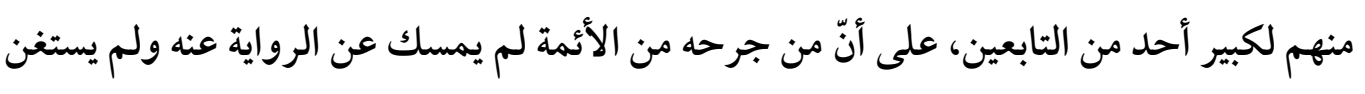

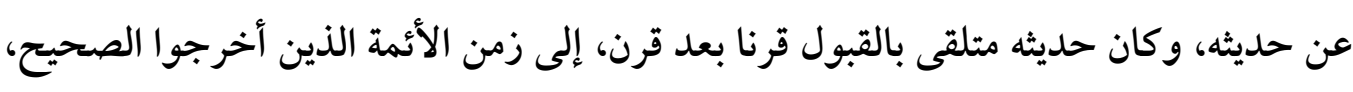

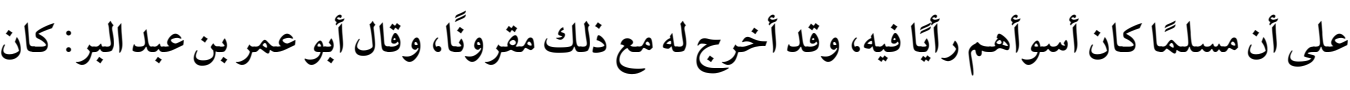

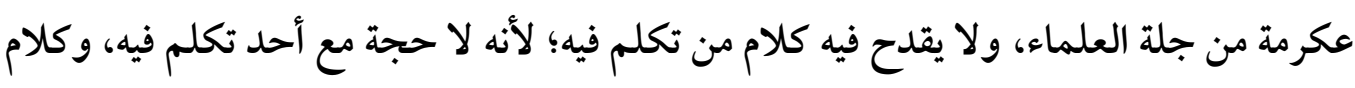

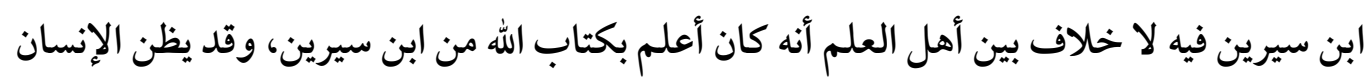

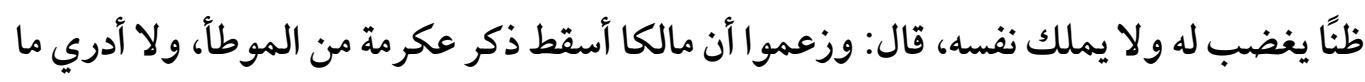

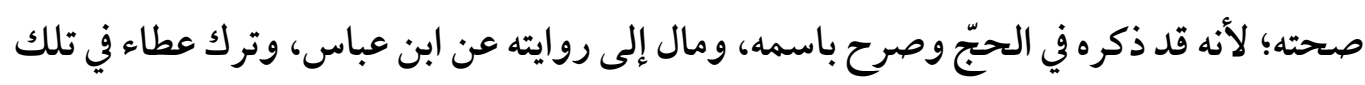

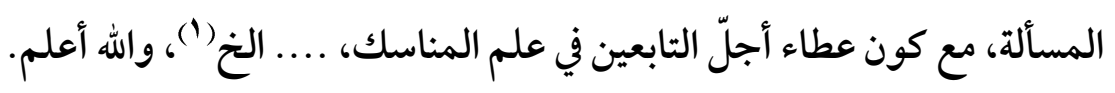
17 1ا_علي بن الجعد الجوهري (خ خد): هو: علي بن الجعد بن عبيد الجوهري، أبو الحسن البغدادي، مولى بني هاشم.

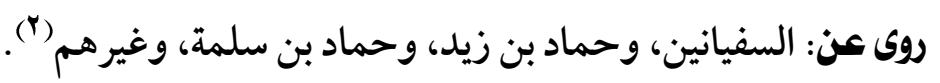

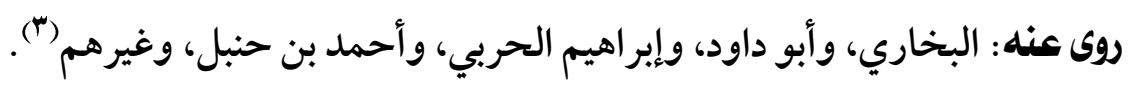

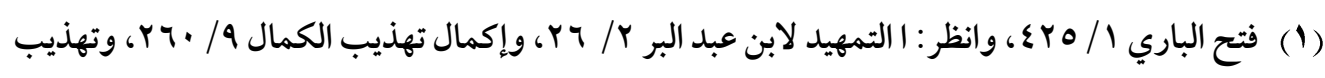
التهذيب / ع عا.

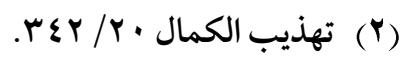

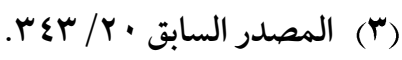




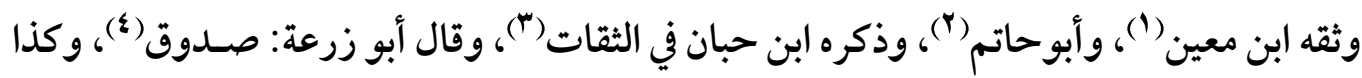

قال النسائي (•)، وقال ابن عدي: لا بأس به("). وقال الجوزجاني: متثـبـث بغير بدعة، زائغ عن الحق(V)، وقال العقيلي: لا يتابع على حديثه(^)،

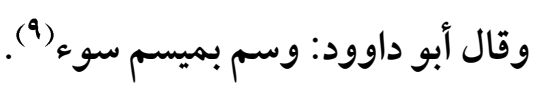
موقف الذهبي منه:

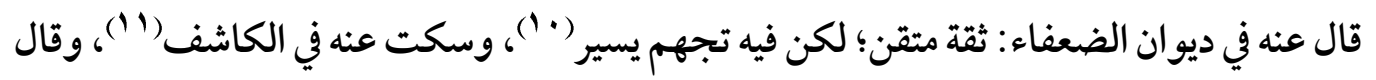
عنه في المغني: حافظ ثبت، ودعه مسلم فلم يخرج له في الصحيح لأنه فيه بدعة(r)، وقال عنه في الميزان: الحافظ الثبت (با")، واستقرّ قوله على أنه: حافظ ثبت لكنه فيه بدعة، وتجهم (\& (). والذي يتزجح: أنه ثقة ثبت، رمي بالتشيع، احتجّ به البخاري وأبو داوود، قال ابن عدي بعد أن نقل

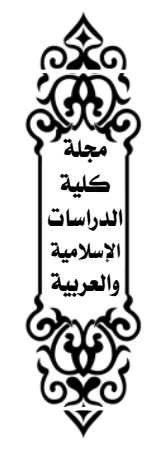

(1) تاريخ ابن معين رواية محرز / ع ـ 1.

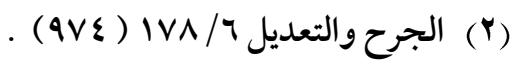

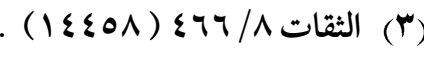

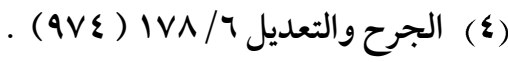

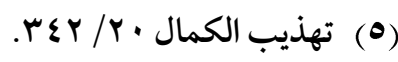

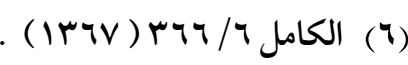
( أحوال الرجال / /

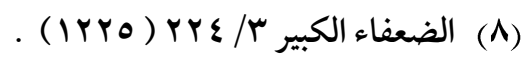

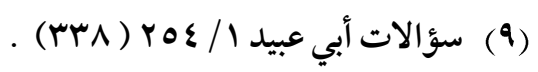
( • (1) ديوان الضعفاء (• (1) ).

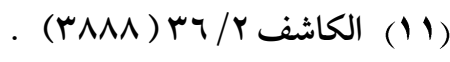

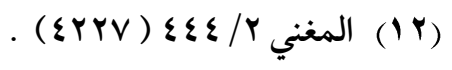

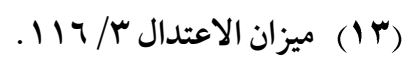

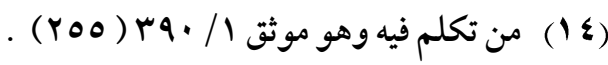




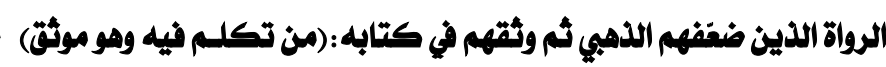

أن ابن حنبل نهى ابنه عن الأخذ عن علي: ومع هَذَا كله علي بْن الجعد ما أرى بحديثه بأسا، ولم أر فِي رواياته إذذا حدث عَن ثقة حديثا منكر ا فيما ذكره، والبخاري مع شدّة استقصائه يروي عَنْهُ فِي صحاحه....(1)، قال الذهبي في السير: الإمام، الحافظ، الحجة، مسند بغداد()، وقال في التذكرة: الحافظ الثبت المسند شيخ بغداد(")، وقال ابن حجر في الفتح: أحد الحفاظ( ()، وقال في التقريب: ثقة ثبت رمي بالتشيع (ه)، والله أعلم.

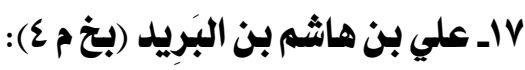

هو: علي بن هاشم بن البريد البريدي العائذي مولاهم، أبو الحسن الكوفي الخزاز("). روى عن: سليمان الأعمش، وإبراهيم بن يزيد الخوزي، وإسماعيل بن أبي خالد، وغيرهم (v). روى عنه: أحمد بن حنبل، وأحمد بن منيع، وإسحاق بن أبي إسرائيل، وغيرهم (A).

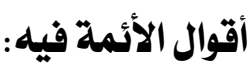

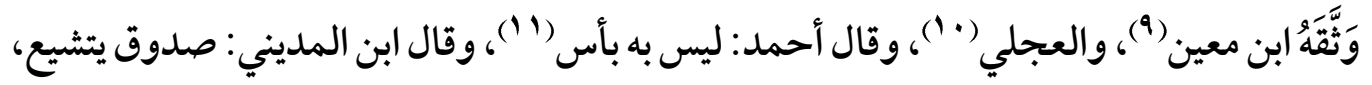

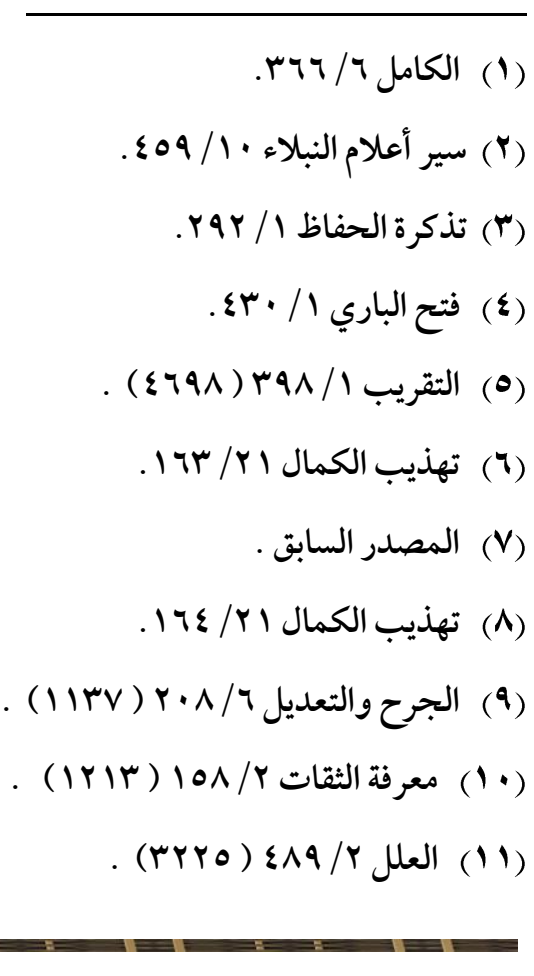


ومرة قال ثقة(')، وقال أبو حاتم: يتشيع، يكتب حديثه(؟)، وقال أبو زرعة: صدوق(汭 وقال ابن

$$
\text { سعد: صدوق صالح الحديث(\&). }
$$

ذكره ابن حبان في الثقات(ه) والمجروحين(")، وقال الجوزجاني: غال في سوء مذهبه(V)، وذكره

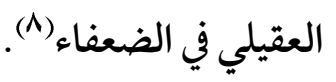
موقف الذهبي منه: قال عنه في ديوان الضعفاء: له مناكير(9)، وقال عنه في الكاشف: شيعي عالم(•(1)، وقال عنه في المغني: صدوق شيعي جلد(1')، وسكت عنه في الميزان(rا')، واستقرّ قوله على أنه: شيعي غال(r)

والذي يترجح: أنه شيعي صدوق، يحتج به بما لا يوافق بدعته، قال ابن عدي: يروي في فضائل علي

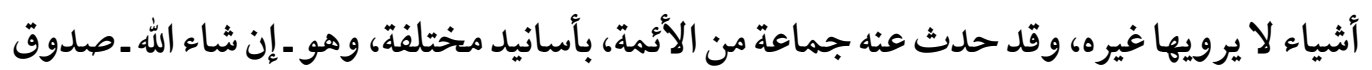

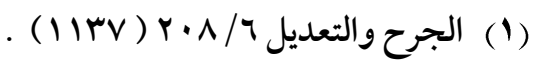

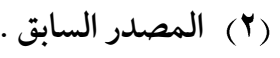
(ب) (ب) المصدر السابق.

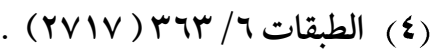

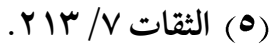

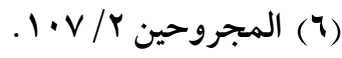

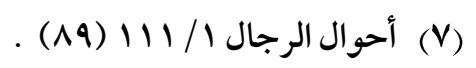

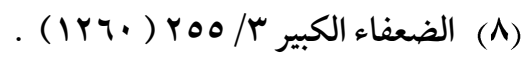

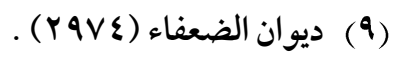

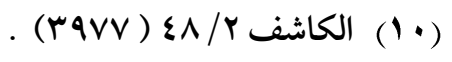

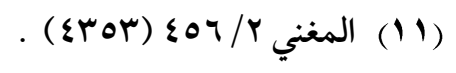

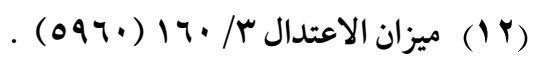

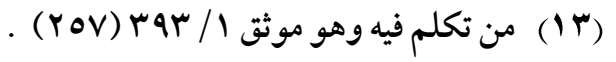




\section{الرواة الدين ضغفهم الدهيي ثم وثقهم في كتابه: (من تكلم نيه وهو موثق)}

في روايته(')، قال ابن حجر في التقريب: صدوق يتشيع()، قال الذهبي: ولغلوه ترك البخاري

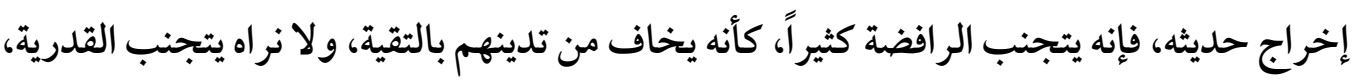
ولا الخوارج، ولا الجهمية، فإنهم على بدعهم يلزمون الصدق (").

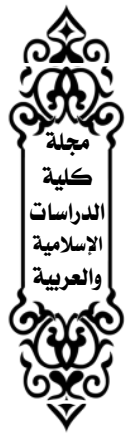

11 اــ كهمس بن المنهال(خ): هو : كهمس بن المنهال السدوسي، أبو عثمان البصري اللؤلؤي. روى عن: الحسن بن عمارة، وسعيد بن أبي عروبة، وعبد الوارث بن سعيد (\&).

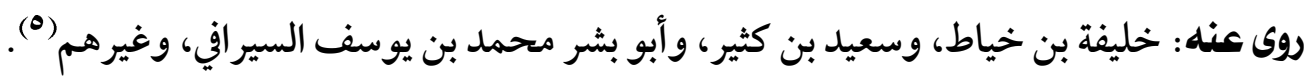

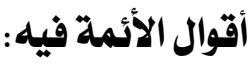
وثقه الدارقطني (")، وقال أبو حاتم: محله الصدق، يكتب حديثه، ويحول من كتاب الضعفاء

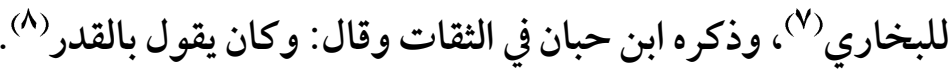

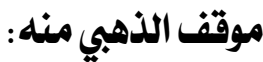
قال عنه في ديوان الضعفاء(9)، وسكت عنه في الكاشف(•) موفئ، وقال عنه في المغني (1) وفي الميزان:

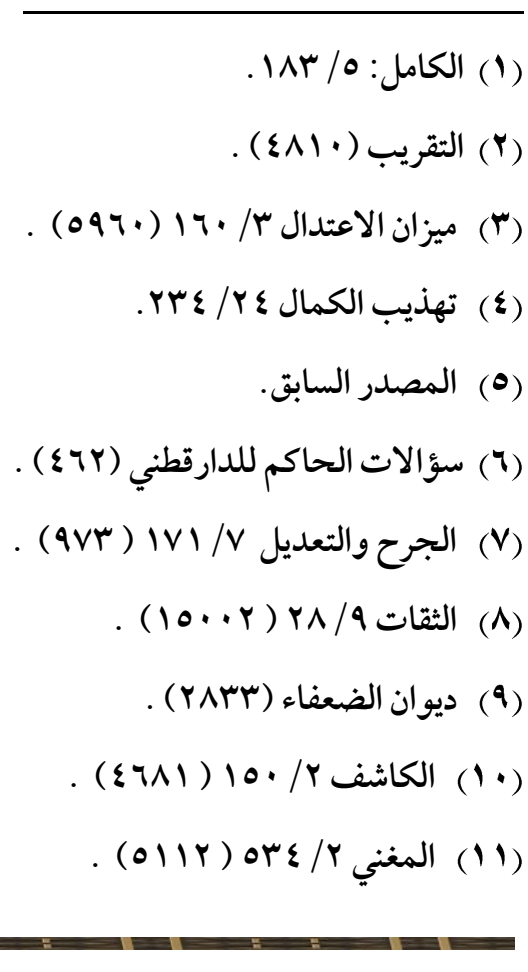


اتهم بالقدر، وله حديث منكر أدخله من أجله البخاري في كتاب الضعفاء(')، واستقرّ قوله على أنه اتهم بالقدر، وله ما ينكر، وقَبَلَهُ بعضهم (َ). والذي يتزجح: أنه صدوق رمي بالقدر؛ كما قاله ابن حجر في التقريب(َ)، قال أبو حاتم: يكتب حديثه، محله الصدق، وقال: يُحَوَّل من كتاب الضعفاء للبخاري (๕)، وقد روى له البخاري حديثًا واحداً مقرونتًا بغيره، ومع ذلك أدخله في كتاب الضعفاء(ه)، والله أعلم.

19_محمد بن حمير الحمصي (خ مد سق ق): هو: محمد بن حمير بن أنيس القضاعي، أبو عبد الحميد، ويقال: أبو عبد الله الحمصي. روى عن: سفيان الثوري، وإسماعيل بن عياش، وبحير بن سعد، وغيرهم (ج). روى عنه: داود بن رشيد، والربيع بن روح، وإبر اهيم بن عبد الله بن خالد، وغيرهم (V).

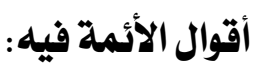

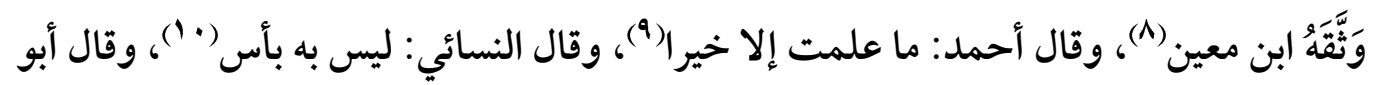

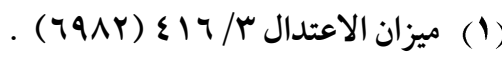

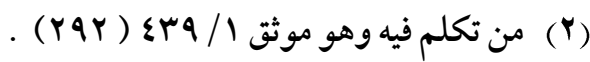

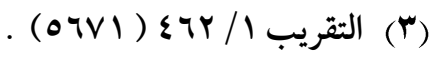
(\&) الجرح والتعديل IVI/V (๑) الضعفاء الصغير: (7) تهذيب الكمال ه/ 1117. 1lV/r/ تهذيب الكمال (V)

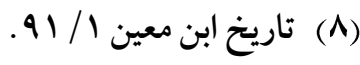

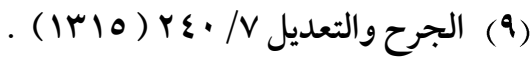
(1) تهذيب التهذيب. 


\section{الرواة الدين ضعفهم الدهبي ثم وثقهم في كتابه :(من تكلم فيه وهو موثق)}

حاتم: يكتب حديثه، لا يحتج به(")، وقال الدارقطني لا بأس به(")، وقال: قد وثقه بعض مشايخنا، وجرحه بعضهم (")، وقال يعقوب بن سفيان الفسوي: ليس بالقوي( (\&). موقف الذهبي منه: ذكره في ديوان الضعفاء وقال: ثقة(ه)، ولم يحكم عليه في الكاشف(ّ)، ولا في المغني (V)، وقال في

الميزان: له غرائب وأفر اد(^)، ولم يحكم عليه أيضا في المختلف فيهم(9).

والذي يترجح: أنه صدوق حسن الحديث؛ قال الذهبي في السير: ما هو بذاك الحجة، حديثه يعد في الحسان، وقد انفرد بأحاديث(·")، وقال ابن حجر في التقريب: صدوق("')، وقد وثقه جمع من الأئمة توثيقا لا يقاومه جرح مبهم كالذي جاء عن يعقوب الفسوي؛ وقد احتج به البخاري في صحيحه، وذكر ابن حجر : أن البخاري أخرج له حديثين: أحدهما: متابعة، والثاني: له أصل عند البخاري من حديث ابن عباس (r) ()، والله أعلم.

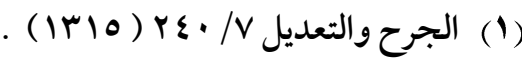

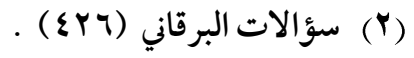

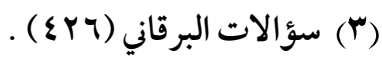

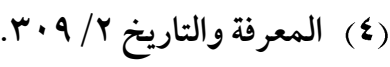

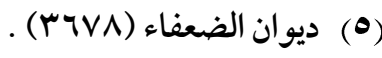

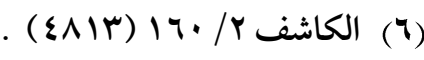
. المغني (V) . ميزان الاعتدال r (^)

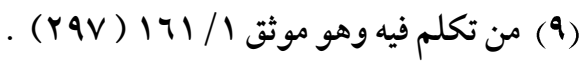

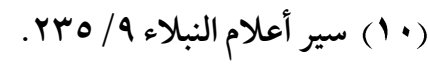

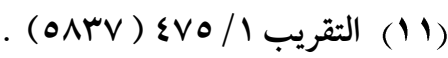

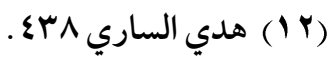




\section{الخاتمــــة}

من خلال ما تقدم تبيّن للباحث ما يأتي:1 - أن كتاب من تكلم فيه وهو موثق، من آخر ما ألّفه الحافظ الذهبي في الجرح والتعديل، بعد أن كثرت مؤلفاته، وناف عمره على الخمسين عاما. ץ-أن هؤلاء الرواة التسعة عشر المذكورون في هذا البحث قد ضعّفهم الذهبي في بداية تأليفه، في كتبه التي ألفها في الجرح والتعديل، أو مال إلى تضعيفهم في كتبه، بنقل كلام المجرحين لهم، ثم السكوت عن ذلك، ثم بدا له إنصافهم فألّف كتابه: من تكلم فيه وهو موثق. r-أن هؤلاء الرواة لا يوجد فيهم من هو شديد الضعف، بل أقلّ أحواله ضعيف يعتبر به. ץ-أن هؤلاء الرواة التسعة عشر تم اختيارهم على أساس أنه يغلب عليهم القبول، وذلك من أصل أربعمائة وخمسة رواة، أودعهم في كتابه المشار إليه. ع - أن من هؤلاء التسعة عشر، عشرة رواة وافق حكم الذهبي فيهم حكم جمهور الأئمة في كونهم ثقات.

ه- أن منهم ستة رواة حكم عليهم الأئمة بحكم صدوق. צ-أن منهم راويين حكم عليهم بالضعف وهما إسماعيل ابن أبي أويس، وعبداله بن عبدالرحمن بن يعلى الطائفي. V- أن منهم راوٍ واحد يصدق عليه المراتب الثلاثة وهي: (ثقة، صدوق، ضعيف)، وهو الإمام عاصم بن أبي النجود. 1-أن مقصود الذهبي في توثيق هؤ لاء الرواة في هذا الكتاب هو إعطاؤهم الحدّ الأدنى من القبول فصاعدا، وهي مرتبة صدوق. 9- من خلال مراجعتي لكلام النقاد في هؤلاء التسعة عشر راويا، والاطلاع على كلام أئمة الجرح والتعديل فيهم، والنظر في مروياتهم، وتطبيقات المحققين في الحكم عليهم وعلى أحاديثهم ظهر لي دقّة كلام الذهبي في ثمانية رواة، أمّا عشرة رواة آخرين فقد ترجح لي أنّهم أعلى مما حكم به 


\section{الرواة الدين ضعفهم الدهبي ثم وثقهم في كتابه (من تكلسم فيه وهو موثق)}

عليهم الذهبي، وراوٍ واحد ترجّح لي أقلّ مما حكم به الذهبي، وقد اعتمدت في ترجيحاتي على نقولات إمّا عن الحافظ الذهبي نفسه، أو عن الحافظ ابن حجر، أو غيرهما، رحمة الله عليهم. • 1 - تنقسم الطعون التي وسم بها هؤلاء التسعة عشر في كتب النقّاد إلى قسمين: البدعة، على اختلاف أنواعها، مثل التشيع، والخوارج، والإرجاء، والقدر، والنصب، وعددهم عشرة رواة، والباقي كان الطعن فيه بسبب حفظه.

11 - جميع هؤلاء التسعة عشر من رجال الكتب الستّة، إما مجتمعين، وعددهم ستة، أو متفرقين، ومنهم راويان لم يرو عنهما البخاري، وستة لم يرو عنهم مسلم، وواحد لم يرو عنه أصحاب السنن

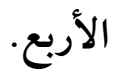
والله أعلم، وصلى الله وسلم على عبده ونبيه محمد وعلى آله وصحبه أجمعين. 


\section{المراجيس}

- أحوال الرجال-المؤلف: إبراهيم بن يعقوب بن إسحاق السعدي الجوزجاني، أبو إسحاق (المتوفى: 9 هـهـ)- المحقق: عبد العليم عبد العظيم البَستوي-دار النشر: حديث اكادمي فيصل آباد، باكستان - بدون تاريخ. -الإرشاد في معرفة علماء الحديث- المؤلف: أبو يعلى الخليلي، خليل بن عبد الله بن أحمد

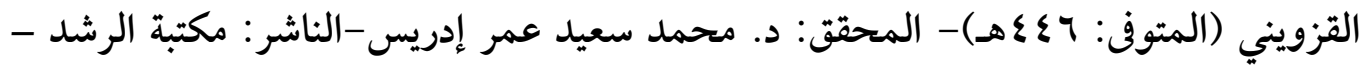

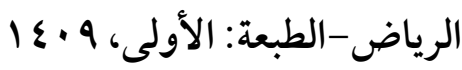

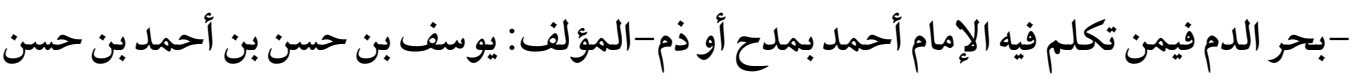
ابن عبد الهادي الصالحي، جمال الدين، ابن ابن المِبرَّد الحنبلي (المتوفى: 9.9هـ)- تحقيق وتعليق: الدكتورة روحية عبد الرحمن السويفي-الناشر: دار الكتب العلمية، بيروت - لبنان-

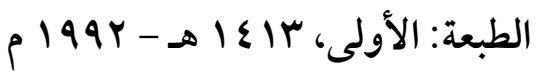
-تاريخ الإسلام وَوَفيات المشاهير وَالأعلام-المؤلف: شمس الدين أبو عبد الله محمد بن أحمد الذهبي (المتوفى: \& Vهـ) - المحقق: الدكتور بشار عوّاد معروف-الناشر : دار الغرب الإسلامي-

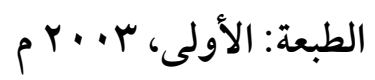
-التاريخ الكبير-المؤلف: محمد بن إسماعيل بن إبراهيم بن المغيرة البخاري، أبو عبد الله (المتوفى: TOYهـ)- الطبعة: دائرة المعارف العثمانية، حيدر آباد - الدكن-طبع تحت مراقبة:

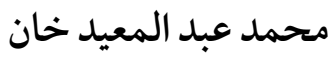

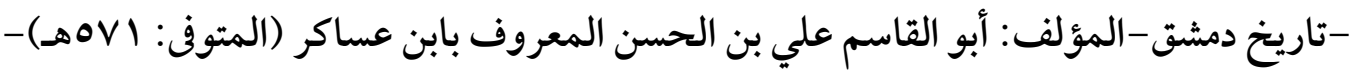
المحقق: عمرو بن غرامة العمروي-الناشر: دار الفكر للطباعة والنثر والتوزيع-عام النشر:

$$
\text { 1990- 1980 }
$$

-التعديل والتجريح، لمن خرج له البخاري في الجامع الصحيح-المؤلف: أبو الوليد سليمان

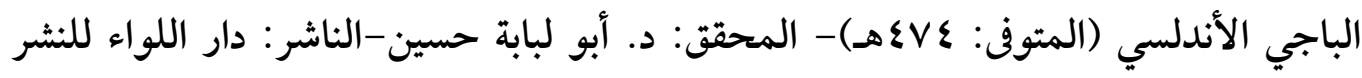




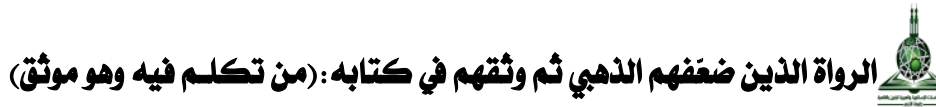

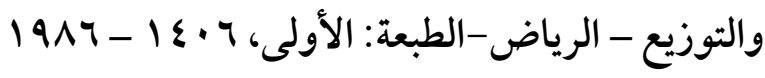

-تقريب التهذيب-المؤلف: أبو الفضل أحمد بن علي بن محمد بن أحمد بن حجر (المتوفى:

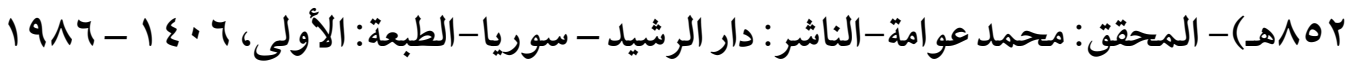
-تهذيب التهذيب-المؤلف: أبو الفضل أحمد بن علي بن محمد بن أحمد بن حجر (المتوفى:

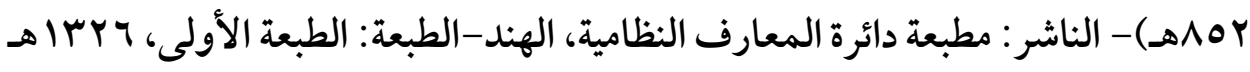
- تهذيب الكمال في أسماء الرجال-المؤلف: يوسف بن عبد الرحمن بن يوسف، أبو الحجاج المزي (المتوفى: Y \& Vه) المحقق: د. بشار معروف-الناشر : مؤسسة الرسالة - بيروت-الطبعة:

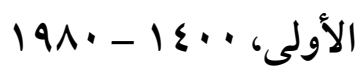

-الثقات-المؤلف: محمد بن حبان البُستي (المتوفى: ؟هبهـ)- طبع بإعانة: وزارة المعارف للحكومة العالية الهندية-تحت مراقبة: الدكتور محمد عبد المعيد خان مدير دائرة المعارف العثمانية-الناشر: دائرة المعارف العثمانية بحيدر آباد الدكن الهند-الطبعة: الأولى، سه با هـ =

-الجرح والتعديل -المؤلف: أبو محمد عبد الرحمن بن محمد بن إدريس بن المنذر التميمي،

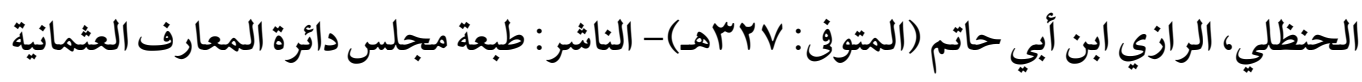

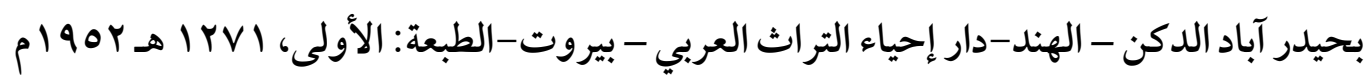
-ديوان الضعفاء والمتروكين - المؤلف: شمس الدين أبو عبد الله محمد بن أحمد الذهبي (المتوفى: V^ \هـ)-المحقق :حماد بن محمد الأنصاري-الناشر مكتبة النهضة الحديثة - مكة

$$
\text { المكرمة- الطبعة الثانية - } 97 V
$$

-الرواة الثقات المتكلم فيهم بما لا يوجب ردهم-المؤلف: شمس الدين أبو عبد الله محمد بن أحمد بن عثمان بن قَائماز الذهبي (المتوفى: \\هـ)- المحقق: محمد إبراهيم الموصلي-

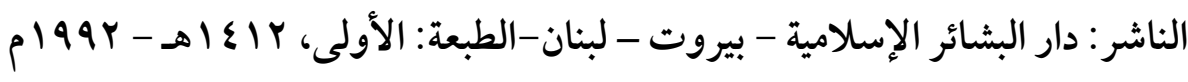
- سؤالات أبي عبيد الآجري أبا داود السجستاني في الجرح والتعديل -المؤلف: أبو داود سليمان 
بن الأشعث السِّحسِتاني (المتوفى: OrVDهـ)- المحقق: محمد علي قاسم العمري-الناشر : عمادة البحث العلمي بالجامعة الإسلامية، المدينة المنورة، المملكة العربية السعودية-الطبعة: الأولى، plast/ols.r -سؤالات البرقاني للدارقطني رواية الكرجي عنه-المؤلف: أحمد بن محمد بن أحمد بن غالب، أبو بكر المعروف بالبرقاني (المتوفى: 0Y\&هـ)- المحقق: عبد الرحيم محمد أحمد القشقريالناشر :كتب خانه جميلي - لاهور، باكستان-الطبعة: الأولى، ع + ع اهـ - سؤالات السلمي للدارقطني - المؤلف: محمد بن الحسين بن محمد بن موسى بن خالد بن سالم

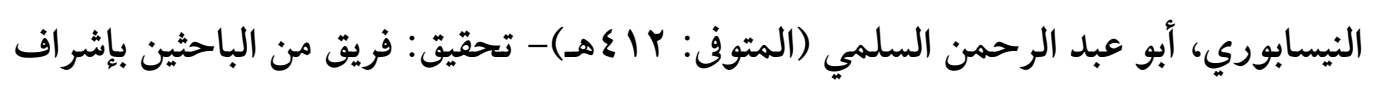

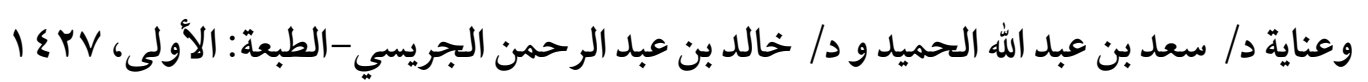

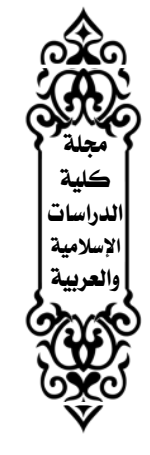

- سؤالات محمد بن عثمان بن أبي شيبة لعلي بن المديني-المؤلف: علي بن عبد الله المديني، البصري، (المتوفى: §rrهـ)- المحقق: موفق عبد الله عبد القادر-الناشر: مكتبة المعارف -

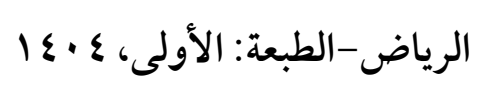

-سير أعلام النبلاء-المؤلف : شمس الدين أبو عبد الله محمد بن أحمد بن عثمان بن قَايْماز الذهبي (المتوفى : V\&Aهـ)- المحقق : مجموعة من المحققين بإشراف الشيخ شعيب

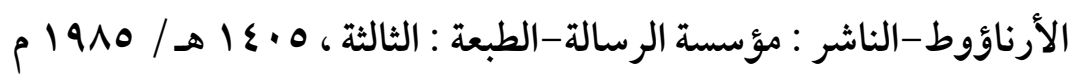
-شرح علل الترمذي-المؤلف: زين الدين عبد الرحمن بن أحمد السَلامي، البغدادي، ثم الدمشقي، الحنبلي (المتوفى: 90 Vهـ)- المحقق: الدكتور همام عبد الرحيم سعيد-الناشر : مكتبة

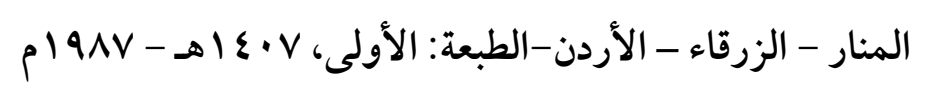

-الضعفاء الكبير-المؤلف: أبو جعفر محمد بن عمرو بن موسى بن حماد العقيلي المكي (المتوفى:MrY.

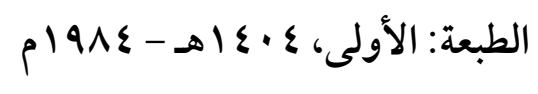




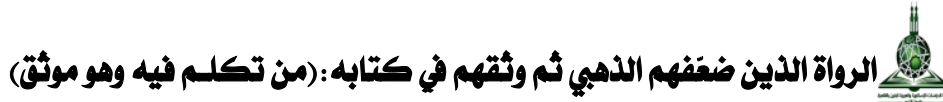

-الضعفاء والمتروكون-المؤلف: أبو عبد الرحمن أحمد بن شعيب بن علي الخراساني، النسائي (المتوفى: ץ.بهـ) -المحقق: محمود إبراهيم زايد-الناشر: دار الوعي - حلب-الطبعة

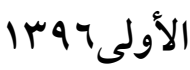

-الضعفاء والمتروكون-المؤلف: جمال الدين أبو الفرج عبد الرحمن بن علي بن محمد الجوزي (المتوفى: Vهـهـ- المحقق: عبد الله القاضي-الناشر: دار الكتب العلمية - بيروت-الطبعة:

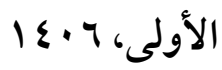

-الطبقات الكبرى-المؤلف: أبو عبد الله محمد بن سعد بن منيع الهاشمي بالولاء، البصري، البغدادي المعروف بابن سعد (المتوفى: · rrهـ)- المحقق: إحسان عباس-الناشر: دار صادر،

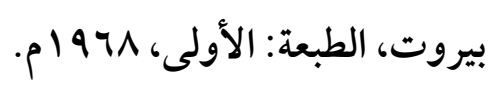

-علل الترمذي الكبير -المؤلف: محمد بن عيسى بن سَوْرة بن موسى بن الضحاك، الترمذي،

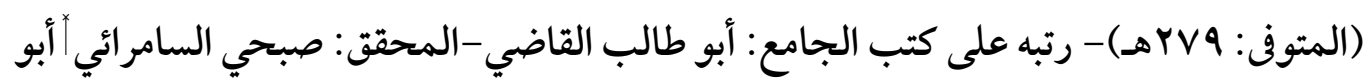

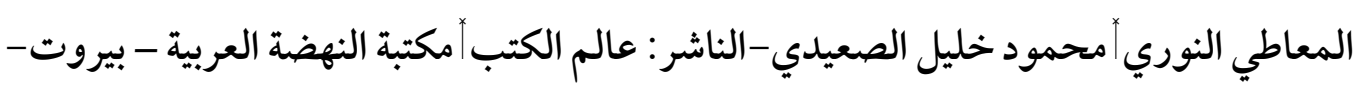

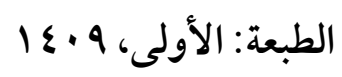

-العلل ومعرفة الرجال-المؤلف: أبو عبد الله أحمد بن محمد بن حنبل (المتوفى: ا؟Yهـ)-

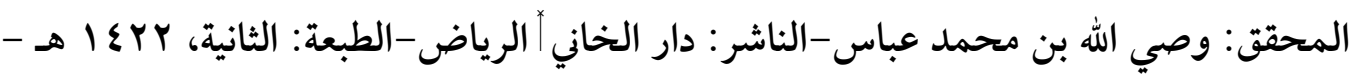

-فتح الباري شرح صحيح البخاري-المؤلف: أحمد بن علي بن حجر أبو الفضل العسقلاني الشافعي-الناشر: دار المعرفة - بيروت، IrV9 -رقم كتبه وأبوابه وأحاديثه: محمد فؤاد عبد الباقي - قام بإخر اجه وصححه وأشرف على طبعه: محب الدين الخطيب -الكاشف في معرفة من له رواية في الكتب الستة-المؤلف: شمس الدين أبو عبد الله محمد بن أحمد بن عثمان بن قَائماز الذهبي (المتوفى: V\هـ)- المحقق: محمد عوامة أحمد محمد نمر الخطيب-الناشر: دار القبلة للثقافة الإسلامية - مؤسسة علوم القرآن، جدة-الطبعة: الأولى، 


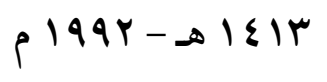

-الكامل في ضعفاء الرجال-المؤلف: أبو أحمد بن عدي الجرجاني (المتوفى: 07هـ)- تحقيق: عادل أحمد عبد الموجود-علي محمد معوض-شارك في تحقيقه: عبد الفتاح أبو سنة-الناشر:

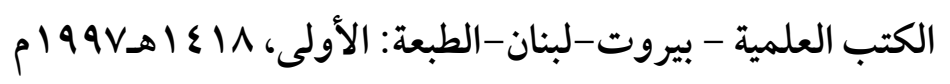

-كتاب الضعفاء-المؤلف: محمد بن إسماعيل البخاري، أبو عبد الله (المتوفى: بهـهـ)المحقق: أبو عبد الله أحمد بن إبراهيم بن أبي العينين-الناشر: مكتبة ابن عباس-الطبعة: الأولى له

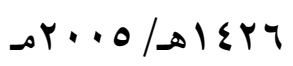

-الكفاية في علم الرواية-المؤلف: أبو بكر أحمد بن علي بن ثابت بن أحمد بن مهدي البغدادي (المتوفى: بآهـ)- المحقق: أبو عبداله السورقي لَ إبراهيم حمدي المدني-الناشر: المكتبة

$$
\text { العلمية - المدينة المنورة }
$$

-لسان الميزان-المؤلف: أبو الفضل أحمد بن علي بن محمد بن أحمد بن حجر العسقلاني (المتوفى: rorهـ)- المحقق: عبد الفتاح أبو غدة-الناشر: دار البشائر الإسلامية-الطبعة: الأولى،

- المجروحين من المحدثين والضعفاء والمتروكين -المؤلف: محمد بن حبان بن أحمد بن حبان بن معاذ بن مَعْبَ، التميمي، أبو حاتم، الدارمي، البُستي (المتوفى: عهـهـ)- المحقق: محمود إبر اهيم زايد-الناشر : دار الوعي - حلب-الطبعة: الأولى، 97 با هـ - معرفة الثقات من رجال أهل العلم والحديث ومن الضعفاء وذكر مذاهبهم وأخبارهم -المؤلف: أبو الحسن أحمد بن عبد الله بن صالح العجلى الكوفي (المتوفى: الجYهـ)- المحقق: عبد العليم

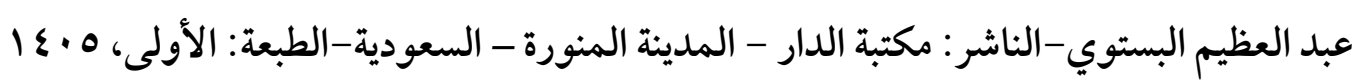

- معرفة الرجال عن يحيى بن معين وفيه عن علي بن المديني وأبي بكر بن أبي شيبة ومحمد بن

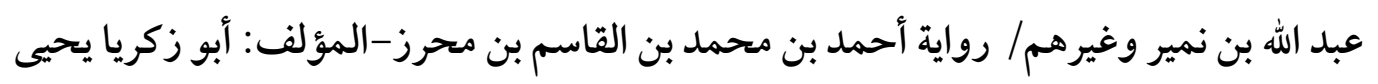




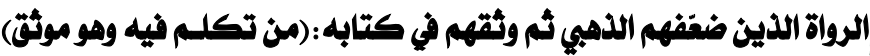

بن معين بن عون بن زياد بن بسطام بن عبد الرحمن المري بالو لاء، البغدادي (المتوفى: سبr هـ)المحقق: الجزء الأول: محمد كامل القصار-الناشر: مجمع اللغة العربية - دمشق رئالطبعة:

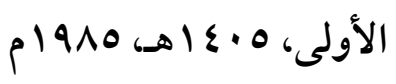

- المعرفة والتاريخ-المؤلف: يعقوب بن سفيان بن جوان الفارسي الفسوي، أبو يوسف (المتوفى:

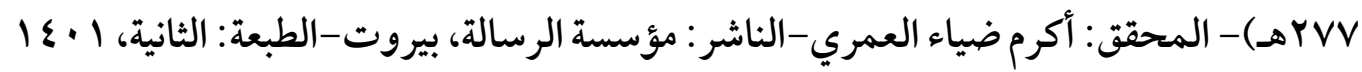

$$
\text { هـ- 1911) }
$$

-المغني في الضعفاء-المؤلف: شمس الدين أبو عبد الله محمد بن أحمد بن عثمان بن قَايْماز الذهبي (المتوفى: \؟ \هـ)- المحقق: الدكتور نور الدين عتر -بدون تاريخ

-من تكلم فيه وهو موثق أو صالح الحديث-المؤلف: شمس الدين أبو عبد الله محمد الذهبي

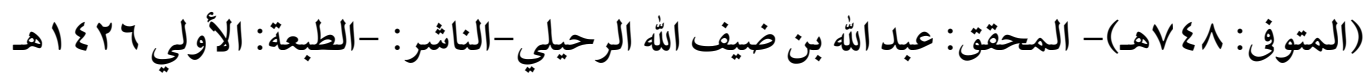

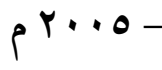

- من كلام أبي زكريا يحيى بن معين في الرجال (رواية طهمان) - المؤلف: أبو زكريا يحيى بن معين بن عون بن زياد بن بسطام بن عبد الرحمن المري بالو لاء، البغدادي (المتوفى: بسجهـ)- المحقق:

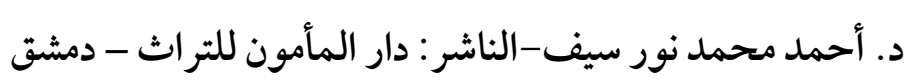
-ميزان الاعتدال في نقد الرجال-المؤلف: شمس الدين أبو عبد الله الذهبي (المتوفى: ^§هـ)تحقيق: علي محمد البجاوي، الناشر: دار المعرفة للطباعة والنشر، بيروت، الطبعة: الأولى،

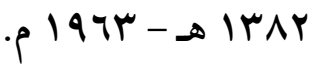




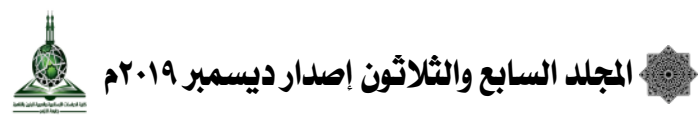

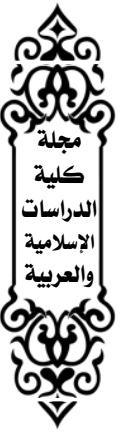

